\title{
Afet Yönetimi ve Planlaması Perspektifinden Türkiye Afet Müdahale Planının Değerlendirilmesi
}

\author{
Ali Utku ŞAHIN ${ }^{1}$
}

\section{Öz}

Yönetim biliminin kendisine özgü bir dalı olarak kabul edilebilecek afet yönetiminin, yönetim biliminin temel fonksiyonlarını kendisini meydana getiren amaca uygun şekilde yorumlaması ve uygulaması beklenebilecektir. Bilindiği üzere plan ve planlama süreci, yönetim ve ilgili faaliyetler açısından amaca giden yolun en önemli parçasını oluşturmaktadır. Bu bakımdan planlama süreci sonucunda elde edilen planlar, bir işin olması gerektiği gibi yürütülebilmesinin önemli bir koşulu olarak değerlendirilmelidir. Bu nedenle, afet yönetimi içerisinde de planlama sürecinin ve süreç sonucunda elde edilen planların, tıpkı yönetim bilimindeki gibi fakat afet yönetiminin kendisine özgü koşulları dikkate alınarak yürütülmesi, üretilmesi ve işletilmesi beklenmelidir. 2014 yılında yürürlüğe giren Türkiye Afet Müdahale Planını bu ilkeler ışığında yeniden okuma ve değerlendirme amacını taşıyan bu çalışmada elde edilen bulgular, Türkiye'nin afet yönetimine ilişkin uzun dönemli bir ulusal stratejiye ve bu stratejiyi destekleyecek yeni ve tek bir yasal altyapıya olan intiyacını ortaya çıkarmaktadır.

\section{Anahtar Kelimeler: Türkiye Afet Müdahale Planı (TAMP), Afet Yönetimi, Planlama}

\section{Evaluation of the Turkey's National Disaster Response Plan from the Point of Disaster Management and Disaster Planning}

\begin{abstract}
Disaster management could be acknowledged as a specific field of administrative sciences. In this regard, it could be expected that the principles of administrative sciences will be evaluated to correspond with the main objectives of disaster management and will be applied for these objectives. As it's known that plans and planning process are the key factors of administrative practices. In this context, plans produced as a result of the planning process should be considered as an important prerequisite for the proper application of a work or a practice. For this reason, in disaster management, the planning process and the plans produced as a result of this planning process should be expected to be carried out, produced and applied as it's done in the administrative sciences but also the specific conditions of disaster management should have been taken into consideration. In another words, disaster planning should be relevant both with the principles of administrative sciences and the specific conditions and necessities of disaster management. This study aims to re-read and evaluate Turkey's National Disaster Response Plan which came into force in 2014 in the light of the planning principles of both administrative sciences and disaster management. Findings reveal that Turkey is in need of a long-term national disaster management strategy and also a new and integrated legal regulation in disaster management to support this strategy.
\end{abstract}

Keywords: Turkey's National Disaster Response Plan, Disaster Management, Planning

\footnotetext{
${ }^{1}$ Acil Yardım ve Afet Yönetimi Bölümü, Hatay Mustafa Kemal Üniversitesi, Hatay

*ilgili yazar / Corresponding author: aliutkusahin@gmail.com

Gönderim Tarihi / Received Date: 27.10.2019

Kabul Tarihi / Accepted Date: 11.06.2020
} 


\section{GiRiş}

Dünya genelinde; afet olarak tanımlanabilecek olayların meydana geliş sıklık ve yoğunlukları, özellikle kentleşmenin gözle görülür bir biçimde artmaya başladığı 1950'li yıllar ile birlikte ciddi ve ölçülebilir bir artış eğilimi göstermekte; aynı zamanda afetler daha kompleks bir şekilde ortaya çıkmaktadır. Afetler, ister doğal nedenlerle isterse insan kaynaklı bir şekilde meydana gelsin; meydana geldikleri her coğrafyada, toplumsal yaşamı kısa ve uzun vadede etkilemekte, bu etkileri sonucunda toplumun gelişimini de olumsuz bir biçimde etkilemektedir.

Tarihin tüm dönemlerinde, çeşitli şekillerde afetlere maruz kalan toplumlar, doğaldır ki bu olaylardan kendilerini koruma intiyacı hissetmişler ve bu yönde çeşitli mekanizmalar geliştirmişlerdir. Geliştirilen bu mekanizmalar, o toplumun kendisini nasıl yönettiğiyle ilişkili olduğu kadar, afet ve afet yönetimine olan yaklaşımıyla da ilişkili bir şekilde tasarlanmış; bu bağlamda afet yönetimi, ilgili toplumun yönetim fonksiyonlarından biri haline gelmiştir.

Bilindiği üzere her yönetim faaliyetinde olduğu gibi afet yönetiminde de planlama, eldeki kaynakların etkin ve verimli kullanımıyla yönetim faaliyetinin amacına uygun şekilde sürdürülebilmesi için son derece önemlidir. Bir başka ifadeyle planlama, afet yönetimi içerisinde yürütülecek faaliyetlerin önceden tanımlanan bir tasarımı olarak, yapılması gereken işlere rehberlik etmektedir. Türkiye odaklı olarak hazırlanan bu çalışma, genelde Türk afet yönetimini, özelde ise Türkiye Afet Müdahale Planını kendisine problem sahası olarak belirlemiştir. Bu bakımdan bu çalışma, Türkiye Afet Müdahale Planının analiziyle birlikte, yürütülen planlama faaliyetini yönetim bilimi açısından inceleme iddiasını taşımaktadır.

\section{KAVRAMSAL ÇERÇEVE VE AFET YÖNETIMININ YÖNETIM BÍLIMSEL YÖNÜ}

Evrensel afet yönetimi literatürü, afet ve afet yönetimi kavramları için çokça tanım ve açıklamayı bünyesinde barındırmaktadır. Örneğin Drabek (2007, s. 4) afet kavramını, toplumun şiddetli bir biçimde kayba uğradığı ve toplumsal kaynakların kullanılamadığı olaylar olarak tanımlamaktadır. Pelling'e göre $(2003$, s. 5) ise afet, tehlikelerin ve zarar görebilirliklerin çakışması sonucunda ortaya çıkmaktadır. Tierney (1989, ss.11-39; Karancı, 2005, s. 93) afetleri, "belirli bir coğrafi bölgede, nispeten aniden ortaya çıkan ve kolektif stres yaratan, belli ölçüde kayıp yaşanan ve toplumun yaşantısını sekteye uğratan olaylar" olarak tanımlarken; Bolin (1989, ss. 61-85; Karancı, 2005, s. 93) ise afetleri belirli aralıklarla toplum yaşantısını engelleyen ve stres yaşatan çevresel olaylar olarak ele almaktadır.

Twigg (2015, s. 2), afet kavramını; tehlikelerin doğası ve bu tehlikelerin zararlarına olan maruziyet ile bu maruziyet altında bulunan insanlar ve varlıkların zarar görebilirliği ve bunların olası tehlikeyi azaltma veya olası tehlikeyle başa çıkabilme kapasitelerinin bir araya gelmesinin sonucu olarak açıklamakta; Birleşmiş Milletler (UNISDR, 2009, s. 9) ise, insanlar için fiziksel, ekonomik ve sosyal kayıplar doğuran, normal yaşamı ve insan faaliyetlerini durdurarak veya kesintiye uğratarak toplulukları etkileyen ve etkilenen topluluğun kendi imkân ve kaynaklarını kullanarak üstesinden gelemeyeceği doğal, teknolojik veya insan kökenli olayların doğurduğu sonuçlar şeklinde tanımlanmaktadır. Afet ve Acil Durum Yönetimi Başkanlığı (2020) da benzer bir tanım yaparak afet kavramını "Toplumun tamamı veya belli kesimleri için fiziksel, ekonomik ve sosyal kayıplar doğuran, normal hayatı ve insan faaliyetlerini durduran veya kesintiye uğratan, etkilenen toplumun baş etme kapasitesinin yeterli olmadığı doğa, teknoloji veya insan kaynaklı olay. Afet bir olayın kendisi değil, doğurduğu sonuçtur." şeklinde tanımlamaktadır. 
Quarantelli'nin afet kavramına yönelik tanımı birden fazla göstergeyle ilişkilidir. Bu tanıma göre afet; aniden ortaya çıkan, kolektif birimlerin rutinlerini ciddi ölçüde bozan, bozulmaya uyum sağlamak amacıyla önceden planlanmamış yöntemlere adapte olmaya neden olan, belirli bir sosyal yer ve zamanda beklenmedik hayat hikâyelerini içeren ve değerli sosyal varlıklara tehdit oluşturan durumlardır (Perry, 2007, s. 10; Quarantelli, 2000, s. 682). Gilbert (1998, s. 13) afetlerin, tehlike kaynaklarının fonksiyonu olmaktan ziyade sosyal kökenli olduğunu belirtmiş; Dynes (1998, s. 13) afetleri, normların bozulduğu ve sosyal kaynakları korumak ve onlardan faydalanmak amacıyla toplumun olağandışı faaliyetlere giriştiği durumlar olarak; Bates ve Peacock (1993, s. 13-14) ise sosyokültürel sistem bozulmalarını içeren bir süreçten doğan sosyal olaylar olarak tanımlamıştır.

Afet kavramına ilişkin tanımlar çoğaltılabilecek olmakla birlikte örneklenen tanımların ortak vurgusu dikkate alındığında afet kavramının; bir olayın veya tehlikenin kendisini değil sonucunu tanımlayan bir kavram olduğu görülmektedir. Bir başka ifadeyle afet kavramı; tehlikeye maruz değerlerin, risk meydana geldikten sonra ortaya çıkan kayıplarının yarattığı "durum"un ifadesi olarak da tanımlanabilir. Bu bakımdan afet, geçmişi ve olmuşu simgeleyen bir kavram olarak değerlendirilmektedir.

Kavrama ilişkin olarak yapılan tanımlar, ayrıca afetlerin, insan yapısı durumları tanımlamakta ve bu durumlar neticesinde ortaya çıkan sonucu adlandırmakta olduğunu da göstermektedir. Bir başka ifadeyle afetin, kaynağın niteliğinden bağımsız olarak ele alınan ve tehlike kaynağının kırılgan toplum yapısıyla karşılaşması sonucunda doğan durumun tanımlanması olduğu görülmektedir. Bu bakımdan afet ifadesiyle kastedilmek istenenin, esasen sosyal yapıdaki bozulmaların bir ölçüsü olduğu değerlendirilmektedir. Bu bağlamda sosyal yapı içerisinde köklü bir biçimde yer alan ve sosyal değişim sürecini etkileyen afet kavramının, sosyal sistem girdi ve çıktılarıyla bireysel baş edebilme kalıpları üzerine olan etki olduğu ifade edilebilecektir (Quarantelli, 2005, s. 339).

Bir durumu ifade eden afet kavramından hareketle tanımlanabilecek olan afet yönetimiyse, bahse konu durumun karşısındaki faaliyetler bütününü tanımlamaktadır. Şöyle ki afet yönetimi, içerik anlamında, afetlerin öncesi, sırası ve sonrasında yapılması gereken bütün işlerin ortak ismi olarak ifade edilebilecektir. Bu bağlamda afet yönetimi; "afet sonucunu doğurabilecek olayların önlenmesi veya zararlarının azaltılması amacıyla, afetlere hazırlık ve onların olası risk ve zararların azaltılması ile birlikte afetlerden sonra müdahale etme ve iyileştirme gibi çalışmaların tümünde yapılması gereken çalışmaların, toplumun tüm kesimlerini kapsayacak şekilde planlanması, yönlendirilmesi, desteklenmesi, koordine edilmesi, gerekli mevzuat ve kurumsal yapılanmaların oluşturulması veya yeniden düzenlenmesi ve etkin ve verimli bir uygulamanın sağlanabilmesi için toplumun tüm kurum ve kuruluşlarıyla, kaynaklarının bu ortak amaçlar doğrultusunda yönetilmesi” (Kadıoğlu, 2011, s. 48) şeklinde tanımlanabilecektir.

Afet yönetiminin yönetim bilimsel yönünün anlaşılması, bu çalışma kapsamında hedeflenen analizlerin anlamlı olabilmesi adına önem arz etmektedir. Bu bakımdan tıpkı afet yönetimi gibi, yönetim kavramının da tanımlanması gerekecektir. Parlak $(2013$, s. 2) yönetim kavramını belirli bir amaç doğrultusunda, birden fazla insanın gerçekleştirdiği işbirliğine dayalı faaliyetler şeklinde tanımlamaktayken; Daft'a (2009, s. 5) göre ise yönetim; planlama, organize etme, yönetme ve kontrol etme fonksiyonları yoluyla organizasyonel kaynakları etkin ve verimli bir şekilde kullanarak organizasyonel amaçlara ulaşma faaliyetidir.

Planlama, organizasyon, yürütme, koordinasyon ve denetim fonksiyonları üzerinden incelenen yönetim kavramına ilişkin tanımlar, bir faaliyetin veya faaliyetler grubunun yönetim faaliyeti olarak adlandırılmasının bazı koşullara bağlı olduğu göstermektedir. Buna göre yapılan faaliyetlerin yönetim olarak adlandırılabilmesi için öncelikle bir amacın ve işbirliğinin 
varlığından söz edilmesi gerekecektir. Ek olarak, belirlenmiş amaç doğrultusunda kurulan işbirliğinin de, eldeki kaynakları etkin ve verimli bir şekilde kullanması gerekmektedir.

Ortaya konulan bu gereklilikler, afet yönetimi kavramı için yapılan tanımlarla birlikte değerlendirildiğinde de benzer bir değerlendirmenin yapılması mümkündür. Şöyle ki afet yönetimi de, tıpkı yönetim için olduğu gibi, belirli bir amaca ve bu amaç doğrultusunda işbirliğine dayanmakta ve eldeki kaynakları etkin ve verimli bir biçimde kullanacak bir organizasyona intiyaç duymaktadır. Bu anlamda afet yönetimi de, yönetim biliminin kendisine özgü bir kolu olarak yönetim kategorisi altında incelenebilecektir. Bir başka ifadeyle, yönetim faaliyetinde olduğu gibi, afet yönetimi ve afet yönetimi kapsamında yürütülen faaliyetlerde de, yönetim bilimsel ilkeler ve temel fonksiyonlar değişmeyecek; afet yönetimi de aynı prensipler doğrultusunda uygulanabilecektir.

\section{AFET YÖNETIMINDE PLANLAMA VE ORGANIZASYON}

Önceki başlıkta kavramsal açılardan kısaca tartışıldığı üzere yönetim biliminin kendisine özgü bir kolu olarak nitelendirilebilecek afet yönetiminin, doğal olarak kendi iç uygulamalarında da yönetim bilimi prensiplerine riayet etmesi beklenebilecektir. Bir başka ifadeyle afet yönetimi, yönetim biliminin temel fonksiyonlarını, kendisini meydana getiren amaca uygun şekilde yorumlayacak ve yine bu amaç doğrultusunda uygulamaya çalışacaktır. Bu durumda afet yönetiminde de işleyiş, yönetim bilimindeki işleyişi takip edecektir.

Öncelikle belirtilmesi gerekir ki yönetimin fonksiyonları, bir sıralamayı belirtmektedir. Başka bir deyişle yönetim faaliyetinin beklenen ve istenen sonuçlarını ortaya çıkarması ancak, önce yapılması gereken işlerin planlanmasıyla, sonra yapılan plana uygun organizasyonun kurulmasıyla, organizasyonun sevk ve idaresinin koordinasyon esaslarına göre sağlanmasıyla ve yürütülen tüm faaliyetlerin amaca ve planlamaya olan uygunluğunun denetlenmesiyle mümkün olacaktır. Bu bakımdan değerlendirildiğinde yönetimin fonksiyonları arasında birbirine bağlı bir ilişkinin bulunduğu ve bir fonksiyondaki olumlu veya olumsuz değişimin o fonksiyondan sonra gelen fonksiyonların işleyişini de etkileyeceği iddia edilebilecektir.

Yönetimin fonksiyonları arasındaki ilişkide iddia edilebilecek bir diğer hususun da, bahse konu fonksiyonlar arasından planlama ve organizasyon fonksiyonunun, diğerlerine göre daha önemli olduğudur. Şöyle ki, fonksiyonlar arası ilişki incelendiğinde, yürütme ve koordinasyonun ancak bir organizasyonun mevcudiyeti durumunda; denetimin ise ancak bir planın varlığı durumunda işlevini yerine getirebileceği görülebilmektedir. Bu durumda planlama ve organizasyon, yönetimin en önemli iki parçasını oluşturmaktadır.

Yönetimin kendisine özgü bir şekli olarak nitelendirilebilecek afet yönetimi ve afet yönetimi içerisinde yürütülen tüm faaliyetler için de, yukarıda sayılan ilişkiler ağı ve prensipler geçerli olacaktır. Hatırlanacağı üzere afet yönetimi, afet sonucunu doğurabilecek olayların önlenmesi veya zararlarının azaltılması amacıyla yürütülmesi gereken faaliyetleri kapsayan sistemi tanımlamaktaydı. Bu tanımdan hareketle afet yönetiminin de, yönetimin diğer alanlarında olduğu gibi, kendi amaçları doğrultusunda hazırlanmış bir plana ve bu planı işletecek bir organizasyona intiyacı olduğu ifade edilebilecektir.

Ancak afet yönetimi için, tek bir plandan söz etmek mümkün olmayacaktır. Şöyle ki, özellikle afet yönetimi sisteminin kapsadığı süreç dikkate alındığında; afet öncesi, afet sırası ve afet sonrasında yapılacak bütün faaliyetleri içerdiği görülecektir. Bir başka ifadeyle afet yönetimi, kendi alanında topyekûn bir sistemi tanımlamaktadır. Bu nedenle afet yönetiminde planlama süreci de, afet öncesi dönemde yapılacak çalışmaları, afet sırasındaki müdahale 
faaliyetlerini ve afet sonrasındaki iyileştirme sürecini kapsar nitelikte olmalıdır. Bu anlamda afet yönetimi sürecinin de, farklı alanlardaki yönetim faaliyetlerinde olduğu gibi, yönetimin temel ilkeleri ve prensiplerine uygun şekilde işlemesi beklenmelidir (Tablo 1).

Tablo 1'de yönetim ve afet yönetiminin planlama ve organizasyon süreçlerine ilişkin gösterilen akışın daha iyi anlaşılabilmesi için, bu akışın her iki alan için de kısaca açıklanması gerekecektir. Yönetim kavramının tanımından da hatırlanacağı üzere her yönetim faaliyetinin belirli amaç veya amaçlar doğrultusunda olması gerekmektedir. Bu bakımdan yönetimin birinci sıradaki fonksiyonu olan planlamanın da, bu belirlenen amaca uygun olması; bir başka ifadeyle başta planlama olmak üzere tüm yönetim süreci sonucunda ulaşılmak istenilen hedefin tanımlanmasıyla başlaması gerekecektir.

Tablo 1. Yönetim ve Afet Yönetiminde Planlama ve Organizasyon Süreçleri (Parlak (2013, ss.169-183) ve Canton (2007, ss. 127-171)'dan faydalanılarak yazar tarafından hazırlanmıştır.)

\begin{tabular}{|c|c|c|}
\hline \multirow{2}{*}{ Fonksiyon } & \multicolumn{2}{|r|}{ Süreç } \\
\hline & Yönetim & Afet Yönetimi \\
\hline Planlama & $\begin{array}{l}\text { 1. Amaçların tespit } \\
\text { edilmesi } \\
\text { 2. Çevresel şartların } \\
\text { araştırılması } \\
\text { 3. Uygulanabilecek } \\
\text { alternatiflerin } \\
\text { incelenmesi } \\
\text { 4. En uygun alternatifin } \\
\text { belirlenmesi } \\
\text { 5. İkincil planların } \\
\text { hazırlanması } \\
\text { 6. Sürecin denetimi ve } \\
\text { güncellenmesi }\end{array}$ & $\begin{array}{l}\text { 1. Ulusal afet yönetimi stratejisi } \\
\text { 2. Risk ve zarar azaltma stratejisi } \\
\text { a. Tehlikelerin tespiti } \\
\text { b. Risklerin analizi } \\
\text { c. Risk yönetimi yaklaşımları } \\
\text { 3. Müdahale stratejisi } \\
\text { a. Öncelikler } \\
\text { b. Yetki ve sorumluluklar } \\
\text { c. Organizasyon } \\
\text { 4. İyileştirme stratejisi } \\
\text { a. Kısa dönem stratejileri } \\
\text { b. Uzun dönem stratejileri }\end{array}$ \\
\hline Organizasyon & $\begin{array}{l}\text { 1. Görülecek } \begin{array}{l}\text { işlerin } \\
\text { belirlenmesi ve } \\
\text { gruplandırıması }\end{array} \\
\text { 2. İş görenlerin tespiti ve } \\
\text { görevlendirilmesi } \\
\text { 3. Yer, amaç ve yöntemin } \\
\text { belirlenmesi }\end{array}$ & \\
\hline
\end{tabular}

Çağdaş organizasyon teorilerinden sistem yaklaşımına göre her sistem kendisini oluşturan alt birimlerin bir bütünü olduğu gibi; aynı zamanda kendisinden daha büyük bir evrenin de bir barçasını oluşturmaktadır. Kısaca her sistem, iç ve dış çevresiyle aktif bir ilişki içerisindedir (Parlak, 2013, ss. 102-103). Bu bağlamda, planlama sürecinin ikinci aşamasını oluşturan çevre koşullarının araştırılması da, sistemin iç ve dış çevresiyle olan ilişkisi ve iç ve dış çevrenin sisteme olan etkilerinin değerlendirilmesiyle ilgili olacaktır (Parlak, 2013, s. 170).

Bir işi yapmanın tek bir yolu bulunmadığından, yapılan çeşitli analizler sonucunda sistemi amaca taşıyacak birden fazla yöntem tespit edilmiş olabilir. Bu kapsamda bir sonraki aşama, bahse konu birden fazla yöntem arasından, sistem veya organizasyon için en uygun olanını seçmek olacaktır. Planlama süreci sonucunda uygulama aşamasına geçildiğinde, uygulamayı destekleyici ek plan ve programlara ihtiyaç duyulacağından, planlama sürecinde bu ihtiyaçların da dikkate alınarak ikincil planların hazırlanması gerekmektedir. Son aşama olan denetim aşamasıysa, yapılması gereken veya yapılan işlerin, planlara ve planlanan amaçlara uygunluğunun denetlenmesi aşamasını oluşturmaktadır (Parlak, 2013, ss. 170171). 
Planlama süreci sonunda elde edilen planların uygulama aracı olan organizasyonların oluşturulması da, kendi içerisinde bir süreci ifade etmektedir. Organize etmenin temeli, iş bölümüne ve uzmanlaşmaya dayanmaktadır. Bir başka ifadeyle organize etme, planlamayla tespit edilen işlerin iş grupları arasında paylaştırılması, işin yapılabilmesi için gerekli yetki ve sorumlulukların tanımlanması ve gereken araç ve ortamın sağlanması anlamına gelmektedir (Parlak, 2013, ss. 179-181).

Yönetim için kısaca aktarılan planlama ve organizasyon süreci, Tablo 1'de afet yönetimi için verilen aynı süreçler anlamında yorumlandığında, birçok aşamanın aynı payda da birleştirilebileceği görülebilecektir. Örneğin yönetim süreci içerisinde amaçların belirlenmesi aşaması, afet yönetiminde ulusal afet yönetimi stratejisiyle; iç ve dış çevrenin sisteme olan etkilerinin tespiti, risk ve zarar azaltma stratejileriyle; uygulamaya dönük alternatiflerin belirlenmesi ve organizasyonel aşamalar da müdahale stratejileriyle aynı altyapı üzerine kurgulanabilecektir.

Hem yönetim hem de afet yönetiminde planlar ve planlama, seviyeye göre değerlendirildiğinde, aralarındaki benzerlik daha belirgin olmaktadır. Örneğin Daft (2009, ss.160-161) planlama sürecinin temel amacın açıklanmasıyla başladığını belirterek planları stratejik, taktik ve operasyonel olmak üzere üç seviyede açıklamaktadır. Kadıoğlu da (2011, s. 134) afet yönetiminde planları olayın meydana geldiği yerden ulusal seviyeye kadar, operasyonel, taktik ve stratejik olmak üzere yine üç seviyede değerlendirmektedir (Şekil 1).
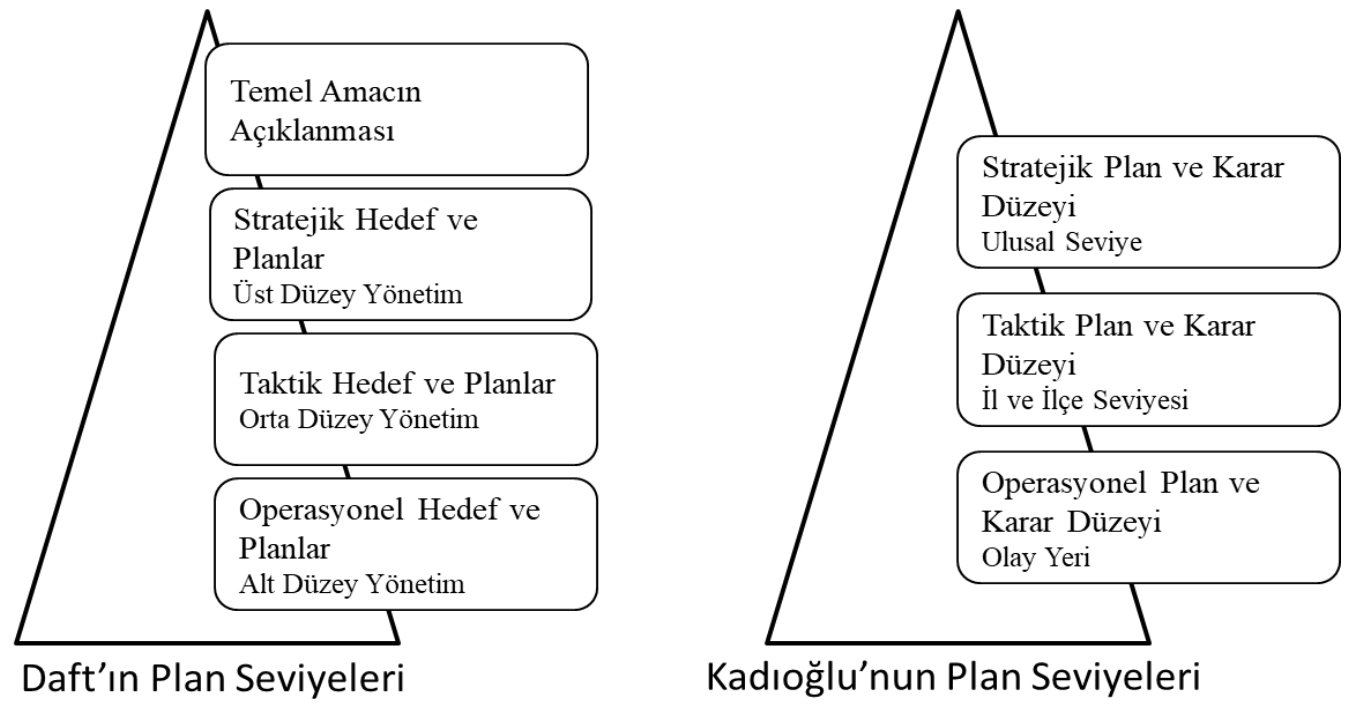

Şekil 1. Daft ve Kadıŏlu'nda Plan Seviyeleri (Daft (2009, s. 160); Kadıoğlu (2011, s. 134))

Şekil 1'de gösterilen seviyeler, temel olarak planlar arası bir hiyerarşik düzenin varlığını da işaret etmektedir. $\mathrm{Bu}$ bağlamda planlar, aralarındaki hiyerarşik düzene göre sınıflandırıldığında, belirli bir düzeydeki her planın iki temel amaca hizmet ettiği görülmektedir. Buna göre bir plan, kendisinden bir üst düzeyde yer alan planlarda tanımlanmış hedeflerin gerçekleştirilmesi için bir araç konumundayken, aynı plan; kendisinden bir alt düzeydeki planlar için de amaç ve hedeflerin göstergesi olmaktadır. Bu planlar hiyerarşisi, sistemi oluşturan her bir unsurun, kendi içerisinde ihtiyaçlara uygun şekilde organize olmasına yardımcı olmaktadır. Bu ilişki dikkate alındığında, sistemin başarılı olabilmesi için öncelikle amaçların ve bu amaçlara uygun hedeflerin tespit edilmesi, daha sonra uygun yöntem ve araçlar kullanılarak planlama sürecine devam edilmesi gerekmektedir (Parlak, 2013, s. 172). 
Tablo 1 ve Şekil 1'de konu edilen sıralı ve hiyerarşik ilişki, temelde afet yönetiminin planlama süreçleri için de geçerli olacaktır. Şöyle ki; afet yönetimi için de, öncelikle ulusal afet yönetimi stratejisinin belirlenmesi, daha sonra zarar verme potansiyeli bulunan unsurlar olarak tehlikelerin ve tehlikenin gerçekleşmesi halinde meydana gelecek kayıp olarak risklerin tespiti ve analizi, tespit edilen risklerin nasıl azaltılabileceğine yönelik stratejilerin belirlenmesi ve uygulanması; afet yönetimi döngüsü içerisinde afet öncesinde yapılması gereken işleri ifade etmektedir. Ancak bu noktadan sonra, bir başka ifadeyle riskler azaltılıp yönetilebilir seviyeye indirildikten sonra müdahale çalışmalarının planlaması ve organizasyonu; müdahale aşaması tamamlandıktan sonra da afet öncesi duruma ve belki de daha iyi bir seviyeye ulaşılabilmesi için iyileştirme stratejisinin uygulanmasına başlanabilecektir.

Bu bakımdan, doğru ve topyekûn bir afet yönetimi için, henüz planlama sürecinde afet yönetiminin risk ve zarar azaltma, hazırlık, müdahale ve iyileştirme süreçlerinin tamamını kapsayacak şekilde çalışılması gerekmektedir. Nitekim Quarantelli $(2003$, s. 217) de, en iyi afet planlama ve yönetim modellerinin sahip olması gereken özellikler içerisinde, klasik afet yönetimi döngüsünün dört aşamasının da var olması gerektiğini vurgulamaktadır.

\section{TÜRKIYE AFET MÜDAHALE PLANI}

Gerek yönetim biliminde gerekse afet yönetiminde planlama ve organizasyon süreçlerine ilişkin olarak buraya kadar aktarılan veriler; her iki alanda da sürecin, birbirine benzer şekilde işlediğini göstermektedir. Her ne kadar, özellikle afet yönetimi içerisinde hem planlama hem de organizasyon süreçleri çok daha geniş kapsamlı süreçler olsa da, özetlenmeye çalışılan veriler; bu çalışmanın konusu olan Türkiye Afet Müdahale Planının analizinde yol gösterici olacaktır.

Bu kapsamda Türkiye Afet Müdahale Planı (TAMP), aşağıda yer verilen konu başlıklarında tespit edilen durumlar ekseninde analiz edilmektedir:

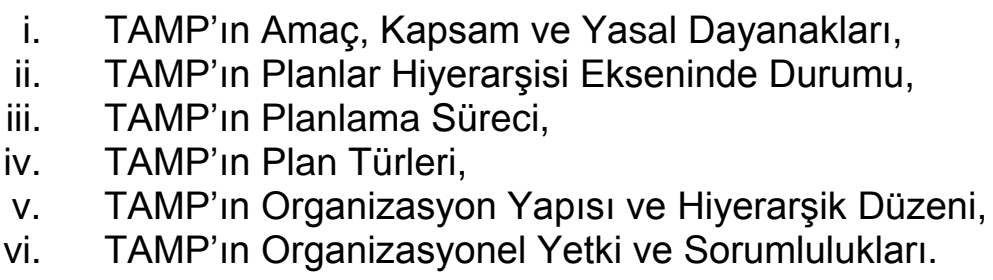

Türkiye Afet Müdahale Planı (TAMP), genel yapısı itibariyle Türkiye'nin afet planlama sistemini temelden değiştirdiği iddiasını benimsemiş bir plandır. Afet ve Acil Durum Yönetimi Başkanlığı (AFAD) tarafından çalışmalarına 2012 yılında başlanan TAMP, 2013 yılında yasal altyapısı olan Afet ve Acil Durum Müdahale Hizmetleri Yönetmeliğinin Resmi Gazetede $^{2}$ yayımlanmasına müteakip, 2014 yılında Resmi Gazetede ${ }^{3}$ yayımlanarak yürürlüğe girmiştir. TAMP, AFAD'ın yayımlamış olduğu stratejik planlama yaklaşımının bir parçası ve 2011 yılında meydana gelen Van Depremi sonrasında başlayan çalışmaların bir ürünü olarak ortaya çıkmıştır (AFAD, 2018, s. 36).

TAMP'ın amacı; "afet ve acil durumlara ilişkin müdahale çalışmalarında görev alacak hizmet grupları ve koordinasyon birimlerine ait rolleri ve sorumlulukları tanımlamak, afet öncesi,

\footnotetext{
${ }^{2}$ Afet ve Acil Durum Müdahale Hizmetleri Yönetmeliği, T.C. Resmi Gazete, 28855, 18.12.2013

${ }^{3}$ Türkiye Afet Müdahale Planı, T.C. Resmi Gazete, 28871, 03.01.2014
} 
sırası ve sonrasındaki müdahale planlamasının temel prensiplerini belirlemek"; kapsamı ise "ülkemizde yaşanabilecek her tür ve ölçekte, afet ve acil durumlara müdahalede görev alacak, bakanlık, kurum ve kuruluşlar, özel kuruluşlar, STK'lar ve gerçek kişiler" olarak tanımlanmaktadır (TAMP, 2013, s.1)

TAMP'ın yasal dayanakları ise, "5902 sayılı Afet ve Acil Durum Yönetimi Başkanlığının Teşkilat ve Görevleri Hakkında Kanun, 7269 sayılı Umumi Hayata Müessir Afetler Dolayısıyla Alınacak Tedbirler İle Yapılacak Yardımlara Dair Kanun, 7126 sayılı Sivil Savunma Kanunu, Afet ve Acil Durum Yönetim Merkezleri Yönetmeliği, Afet ve Acil Durum (Müdahale) Hizmetleri Yönetmeliği, Ulusal Deprem Stratejisi Eylem Planı" olarak ifade edilmektedir (TAMP, 2013, s.1).

Kapsam bakımından TAMP; coğrafi anlamda tüm Türkiye'yi kapsamakta; sorumluluk anlamında Türkiye'deki tüm gerçek ve tüzel kişilere sorumluluk yüklemekte; amaç bakımındansa müdahale çalışmalarının temel prensiplerini belirlemeyi kendisine görev edinmektedir. Yasal dayanakları açısından değerlendirildiğinde TAMP, Türkiye'nin uzun yıllardır afet ve sivil savunma konularındaki faaliyetlerinin yasal altyapısını oluşturan 7269 ve 7126 sayılı Kanunlara dayanmakta; ayrıca AFAD teşkilat kanunundan da yetki almaktadır. Ayrıca TAMP, temel dayanağı olan Afet ve Acil Durum Müdahale Hizmetleri Yönetmeliğiyle de; kendisinden önceki 88/12777 sayılı Yönetmeliği ${ }^{4}$ ilga etmiştir.

Çalışmanın önceki kısımlarından hatırlanacağı üzere afet yönetiminin yapısı, tek bir plan yerine bir planlar grubunun oluşumunu ve kullanımını gerektirmektedir. Bir başka ifadeyle afet yönetimi, afet olarak tanımlanabilecek olayın öncesi, sırası ve sonrasında yapılması gereken tüm faaliyetleri kapsadığından, planlama mekanizmasının da bu üç safhayı kapsayacak şekilde hazırlanması afet yönetiminden beklenen başarı için önem arz etmektedir. Bu bakımdan afet yönetimi bir olayın öncesi, sırası ve sonrası şeklinde, öncülü ve ardılı olan bir süreci de tanımladığından; afet yönetimi için hazırlanacak planların da bu prensipleri koruması beklenmektedir.

Bu bağlamda TAMP, bu prensipler çerçevesinde değerlendirildiğinde, bahse konu öncüllük ve ardıllık hiyerarşisinin ortasında konumlandığı ifade edilebilecektir. Nitekim gerek Türkiye Afet Müdahale Planı olan isminin, gerekse amacının işaret ettiği üzere TAMP, bir müdahale planıdır ve dolayısıyla afet sırasını ilgilendirmektedir. Bu durum TAMP'ın öncül ve ardıl planlarının olmasını da, planlama süreci ve hiyerarşisi dikkate alındığında, zorunlu kılmaktadır.

Nitekim TAMP'ın kendi metni içerisinde açıklanan strateji dikkate alındığında, TAMP'ın öncülü olarak risk ve zarar azaltma stratejisinin ve planının; ardılı olarak da iyileştirme stratejisi ve planının varlığı söz konusudur (Şekil 2) (TAMP, 2013, s.4).

\footnotetext{
${ }^{4}$ Afetlere İlişkin Acil Yardım Teşkilatı ve Planlama Esaslarına Dair Yönetmelik, T.C. Resmi Gazete, 19808, 08.05.1988
} 


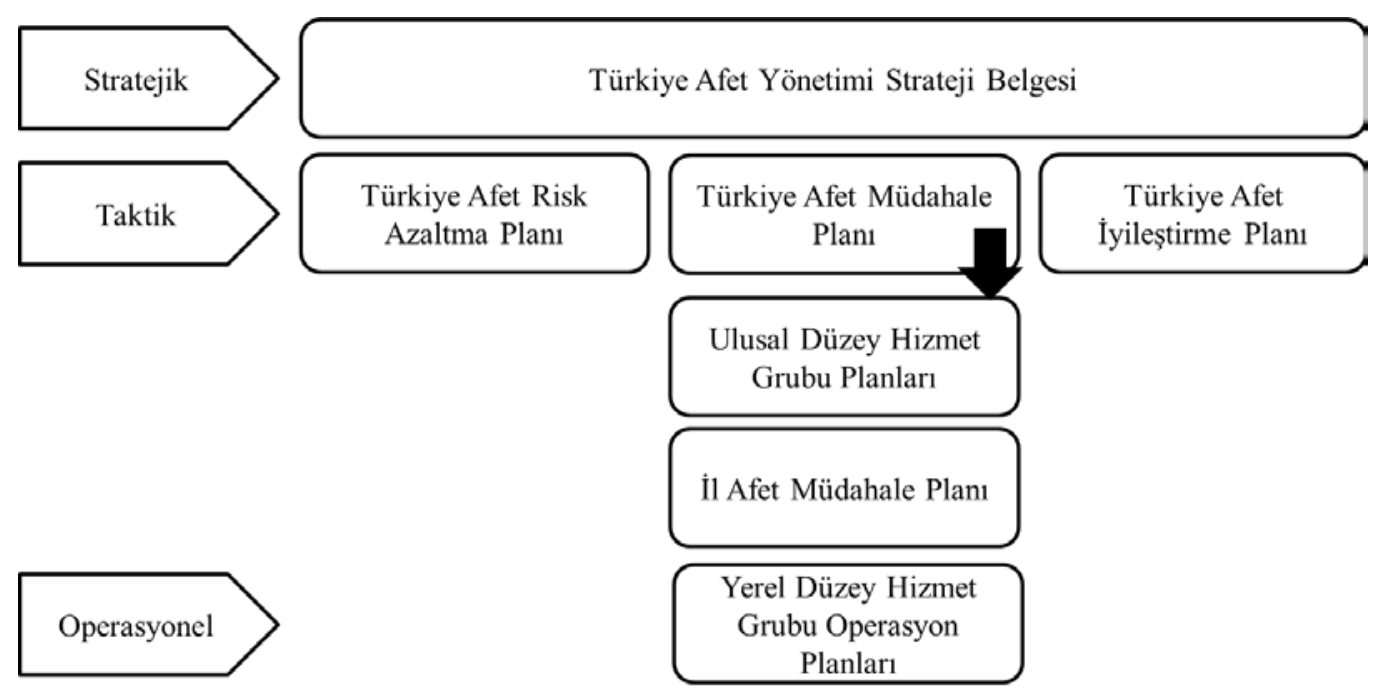

Şekil 2. Türkiye Afet Yönetimi Stratejik Planlama Yaklaşımı (AFAD, 2018, s. 35; TAMP, 2013, s. 4)

Ancak Birleşmiş Milletler Afet Risklerinin Azaltılması Küresel Platformunda yapılan açıklamaların gösterdiği üzere, TAMP'ın öncülü olarak gerek Türkiye Afet Yönetimi Strateji Belgesinin (TAYSB) gerekse Türkiye Afet Risk Azaltma Planının (TARAP) henüz hazır olmadığı; bu strateji ve planlar üzerindeki çalışmaların halen devam ettiği anlaşılabilmektedir (AFAD, 2019a).

Yönetim biliminde fonksiyonlar arasında hiyerarşik bir ilişkinin bulunduğu ve sistemin doğru işleyebilmesi açısından bahse konu fonksiyonlar dahilindeki işlemlerin belirli bir sırayla gerçekleştirilmesi gerektiği, ilgili alt başlık içerisinde açıklanmaya çalışıımıştı. Bu bağlamda yönetim sürecinin planlamayla başlaması; planlamadan sonra gelecek başta organizasyon olmak üzere diğer fonksiyonların da doğru işlemesinin doğal şartı olarak değerlendirilmektedir.

$\mathrm{Bu}$ durumda planlama ve organizasyon fonksiyonları arasındaki ilişki, temel anlamda, planlama süreciyle gelecekte yapılması beklenen ve/veya gereken işlerin tespit edilmesi; organizasyon süreciyleyse tespit edilen bu işlerin belirli kriterler dikkate alınarak gruplandırılması ve bu işleri yapması gerekenlerin yetki ve sorumluluklarının belirlenmesi seviyesinde olmalıdır.

TAMP'ın plan hazırlama süreci incelendiğinde planlamanın organizasyon süreciyle başladığı görülmektedir (TAMP, 2013, s. 5). Bir başka ifadeyle yapılacak iş ve işlemlerin belirlenmesi süreci tamamlanmadan organizasyon süreci başlatılarak planın işletilmesini sağlayacak yetki ve sorumlulukların belirlenmesi aşamasına geçilmiş ve TAMP, bu eksen üzerine kurgulanmıştır. Takip eden süreçteyse, hizmet gruplarının ${ }^{5}$ analiz ve planlaması; senaryo, kapasite geliştirme ve finansman süreçleri ve nihayetinde plan entegrasyonu ve tatbikat süreçlerinin tanımlanmasıyla TAMP çalışmaları tamamlanmıştır (TAMP, 2013, s.5).

Ek olarak TAMP'ın hazırlanma sürecinin, 2011 yılında meydana gelen Van Depremi ve bu depremden öğrenilenlerle de ilişkili olduğu ifade edilmektedir. Nitekim AFAD (2018, s.36) da sürecin Van Depreminden sonra başladığını ve TAMP'ın bahse konu depremde görev alan

\footnotetext{
${ }^{5}$ Afet ve Acil Durum Müdahale Hizmetleri Yönetmeliğinin 4/j maddesine göre hizmet grubu; afet ve acil durumlarda ana çözüm ortağı ve destek çözüm ortaklarının yürüttükleri hizmetlerin niteliğine göre oluşturulan grupları ifade etmektedir (Y.N.).
} 
birçok gerçek ve tüzel kişinin de katılımıyla çok paydaşlı bir şekilde yürütülen iki yıllık bir süreç sonucunda ortaya çıktığını ifade etmektedir.

TAMP'ın; kendi içerisindeki plan türleri incelendiğinde, iki farklı entegrasyon seviyesinde toplam altı farklı plandan oluştuğu görülebilmektedir. Buna göre dikey ve yatay entegrasyon seviyelerinde tasarlanan TAMP ulusal düzeyde; Türkiye Afet Müdahale Planı (planın kendisi), Ulusal Düzey Hizmet Grubu Planları ve Ulusal Düzey Olay Türü Planlarından; yerel düzeydeyse; İl Afet Müdahale Planı, Yerel Düzey Hizmet Grubu Planları ve Yerel Düzey Olay Türü Planlarından oluşmaktadır (Şekil 3) (AFAD, 2018, s. 37).

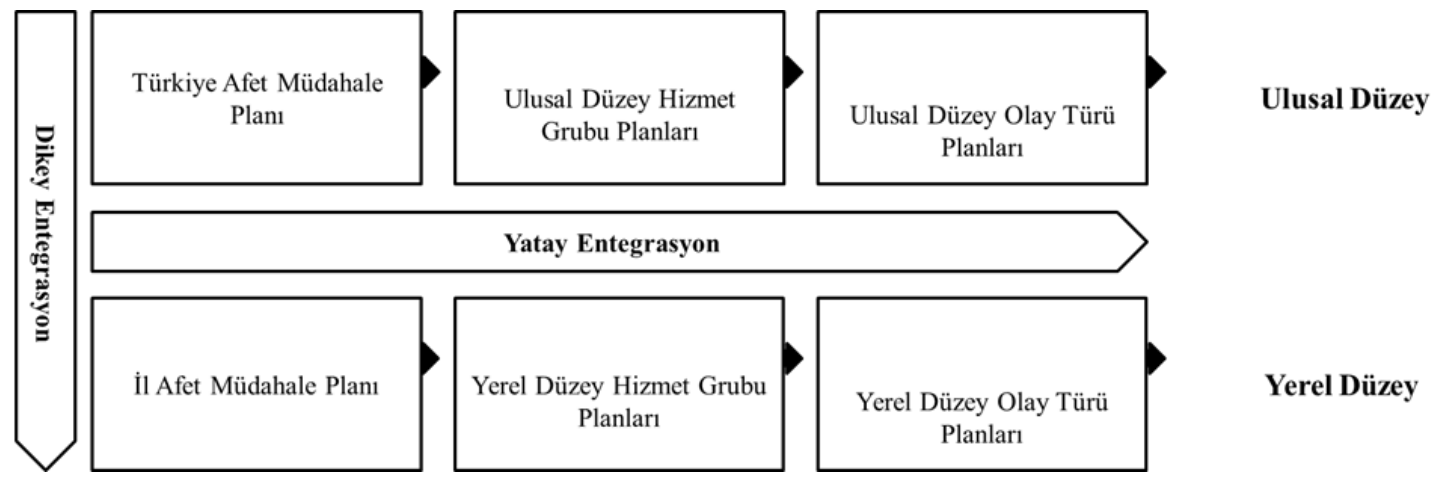

Şekil 3. TAMP Plan Türleri ( AFAD, 2018, s.37; TAMP, 2013, s. 4)

Afet ve Acil Durum Müdahale Hizmetleri Yönetmeliğine göre TAMP, müdahale çalışmalarında görev alacak hizmet grupları ve koordinasyon birimlerine ait görev ve sorumlulukları tanımlamak amacıyla afet öncesi, sırası ve sonrasındaki müdahale planlamasının temel prensiplerini içermektedir (Md. 6). Bu anlamda TAMP, taktik bir yaklaşımla hazırlanmış olup ulusal ve yerel boyutta afet ve acil durumlarda müdahale çalışmalarının nasıl yürütüleceğini ortaya koyan bir üst plan olarak tanımlanmaktadır (TAMP, 2013, s. 2).

Ulusal Düzey Hizmet Grubu Planları, ilgili hizmet grubunun ana çözüm ortağı tarafından destek çözüm ortaklarıyla ${ }^{6}$ birlikte yine taktik bir yaklaşımla hazırlanmakta, hizmet grubu ekipleri bu planlarda oluşturularak her bir ekibin görev, yetki, sorumluluk ve iş akışları belirlenmektedir (TAMP, 2013, s.2).

Il Afet Müdahale Planları afet ve acil durumlara ilişkin müdahale çalışmalarında görev alacak, hizmet grupları ve koordinasyon birimlerine ait görev ve sorumlulukları tanımlamak amacıyla afet öncesi, sırası ve sonrası müdahale planlamasının temel prensiplerini içeren TAMP ile entegre olacak şekilde il ölçeğinde hazırlanmaktadır. Bu kapsamda yerel düzeyde müdahale organizasyon sistemi oluşturulmaktadır (Afet ve Acil Durum Müdahale Hizmetleri Yönetmeliği, Md. 8)

Yerel Düzey Hizmet Grubu Operasyon Planları ${ }^{7}$ da, ulusal düzeydeki karşılığında olduğu gibi, ilgili ana çözüm ortağının taşra teşkilatı tarafından operasyonel bir yaklaşımla ve

\footnotetext{
${ }^{6}$ Afet ve Acil Durum Müdahale Hizmetleri Yönetmeliğinin 4/g maddesine göre ana çözüm ortağı hizmet grubunun yürüteceği hizmetlere ilişkin koordinasyondan sorumlu olan bakanlık, kurum ve kuruluşları; 4/h maddesine göre destek çözüm ortağı hizmet grubunda ana çözüm ortağı olarak görev alan bakanlık, kurum ve kuruluşların çalışmalarında destek olarak görev alan paydaşları ifade etmektedir (Y.N.).

7 Şekil 3'te gösterilen plan türleri içerisinde yer alan Yerel Düzey Hizmet Grubu Planlarıyla, Yerel Düzey Hizmet Grubu Operasyon Planları aynı planlardır. Şekil 3'ün alıntılandığı kaynak eserde planın adı, Türkiye Afet Müdahale Planı metni ve Afet ve Acil Durum Müdahale Hizmetleri Yönetmeliğinden farklı yazılmıştır (Y.N.).
} 
ayrıntılı olarak hazırlanmaktadır. Bu planlarda olay bölgesinde intiyaç duyulabilecek tüm kaynakların mevcut durumu tespit edilmekte ve envanter oluşturulmaktadır (Afet ve Acil Durum Müdahale Hizmetleri Yönetmeliği, Md. 9).

Olay Türü Planlarıysa, hem ulusal hem de yerel seviyede; ulusal ve yerel düzeydeki hizmet grubu planlarının dışında sistem içerisinde duyulan intiyaca göre ve özel olarak belirli olaylara karşı hazırlanabilmektedir (AFAD, 2018, s.37).

Bir müdahale planı olarak TAMP'ın organizasyon yapısının da, afet yönetiminin müdahale süreçlerine uygun bir şekilde organize edilmiş olması beklenmelidir. Nitekim TAMP'ın organizasyon düzeni incelendiğinde, hem ulusal hem de yerel düzeyde bilinen, klasik olay komuta sisteminin kullanıldığı görülebilmektedir (Şekil 4 ve 5).

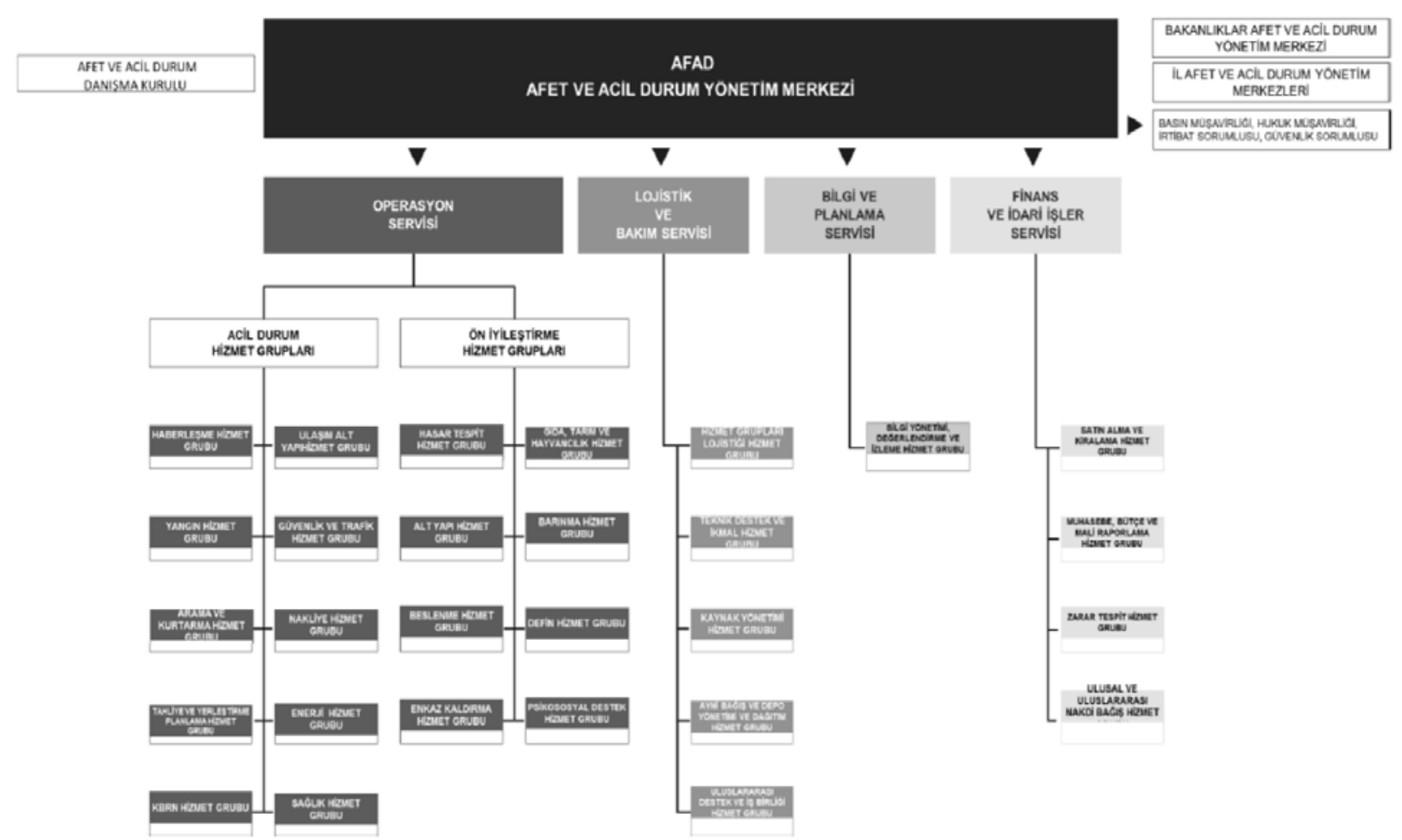

Şekil 4. Ulusal Düzey Organizasyon Sistemi (Ulusal Radyasyon Acil Durum Planı (URAP), 2020) s.5) 


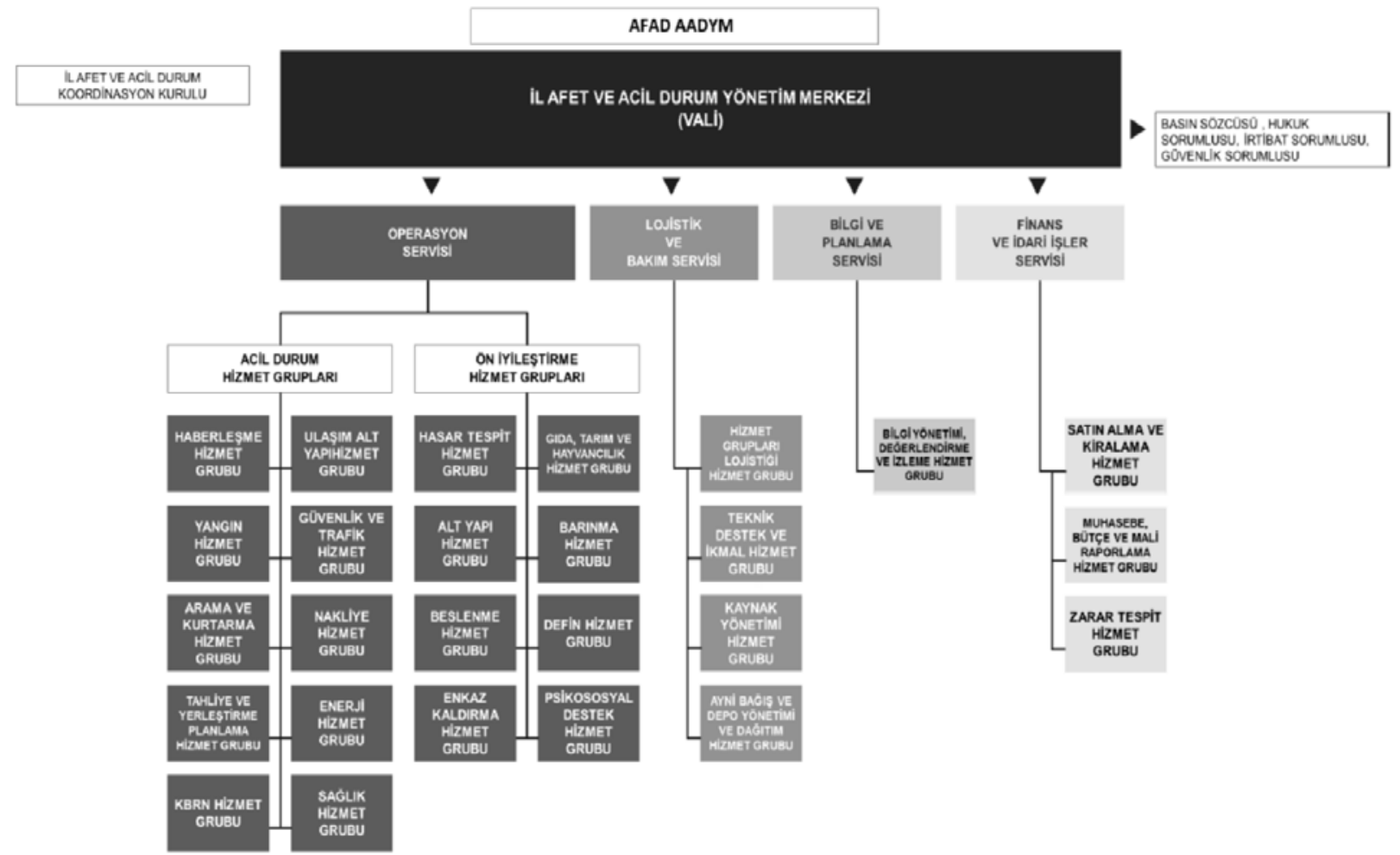

Şekil 5. Yerel Düzey Organizasyon Sistemi(Ulusal Radyasyon Acil Durum Planı (URAP), 2020), s.6)

TAMP'ta uygulanan olay komuta sistemi, ulusal ve yerel düzeylerde dört servis etrafında organize edilmiş olup bu servisler, operasyon, bilgi ve planlama, lojistik ve bakım, finans ve idari işler olarak tanımlanmıştır. Bu servislere bağlı hizmet gruplarıysa, ulusal seviyede 28 , yerel düzeydeyse 26 adet olarak tespit edilmiştir.

Ulusal düzeydeki organizasyon incelendiğinde operasyon servisi, müdahale organizasyonunda temel birim olarak planı uygulamaya geçiren servis olarak tanımlanmaktadır. Müdahale seviyesi ve olay türü yaklaşımıyla iki alt servise ayrılan operasyon servisi içerisinde; küçük ölçekli olaylar için acil durum hizmetleri alt servisi, büyük çaplı afetler içinse ön iyileştirme alt servisi oluşturulmuştur (TAMP, 2013, s. 11). Operasyon servisi toplam 18 hizmet grubundan oluşmaktadır.

Bünyesinde bir adet hizmet grubunu barındıran bilgi ve planlama servisi; bilgi toplama, kayıt altına alma, belgeleme ve raporlama ile değerlendirme ve izleme hizmetlerinin yerine getirilmesinden sorumludur. Bu kapsamda bilgi ve planlama servisi; müdahale süresince veri toplama ve analiz süreçlerinden, keşif ve durum bilgisi sağlamaktan, durum değerlendirmekten, coğrafi bilgi sistemleri verilerini değerlendirmekten, olasılık hesaplamaları ve modellemelerden sorumludur (TAMP, 2013, s. 12).

Müdahale çalışmalarında görev alan hizmet gruplarına destek olmak amacıyla oluşturulan lojistik ve bakım servisi, bu kapsamda tesis kurma, malzeme, ekipman vb. ihtiyaçları temin etme görevlerini bünyesinde kurulan beş hizmet grubuyla gerçekleştirmektedir. Finans ve idari işler servisiyse, servisi oluşturan dört hizmet grubu vasıtasıyla acil intiyaçların temini, oluşan zararın tespiti, nakdi bağışların toplanması ve koordinasyonu, harcamaların kayıt altına alınması görevlerinden sorumludur (TAMP, 2013, ss. 12-23). 
TAMP'ın yerel düzeydeki organizasyon modeliyse, ulusal düzeydeki organizasyon yapısının bir yansıması şeklinde planlanmıştır. Buna göre ulusal düzeyde kurulan organizasyonun aynısı ${ }^{8}$ yerelde il düzeyinde de oluşturulmakta ve hizmet grubu düzeni de, ulusal seviyedeki hizmet gruplarının taşra teşkilatları koordinesinde; fakat operasyonel bir yaklaşımla tasarlanmaktadır (TAMP, 2013, s.13).

TAMP organizasyon düzenindeki yetkilendirmeyi de, yine ulusal ve yerel seviyeler olmak üzere iki başıı altında değerlendirmektedir. Bu bağlamda ulusal seviyede AFAD Afet ve Acil Durum Yönetim Merkezi müdahale çalışmalarının koordinasyonundan sorumluyken; yerel düzeyde yetki vali ve valinin başkanlığında kurulan il afet ve acil durum koordinasyon kuruluna verilmiştir. Yine, koordinasyon anlamında, hizmet gruplarında görevli bakanlıkların kendi bünyelerinde, sorumlusu oldukları hizmet gruplarının koordinasyonunun sağlanabilmesi bakanlık afet ve acil durum yönetim merkezleri ve bu merkezler içerisinde koordinasyon ekipleri, afet bölgesindeki hizmet gruplarına destek olabilmek amacıyla da saha destek ekipleri oluşturulmaktadır (TAMP, 2013, ss.8-10).

TAMP'ın organizasyonel düzeni incelendiğinde, sistemin temel yapısının hizmet grupları üzerinden işletilmek istendiği anlaşılabilmektedir. Bu bakımdan, hizmet gruplarının oluşumu ve hizmet grubu içerisindeki yapının da analize dahil edilmesi gerekecektir. Çalışma içerisinde de daha önce de ifade edildiği üzere hizmet grubu düzenindeki organizasyon, afet sırasında intiyaç duyulabilecek hizmetler etrafında ve ilgili hizmetin esas sorumlusu olan tüzel kişinin koordinasyonunda faaliyetlerin yürütülmesi esasına dayanmaktadır. Bu bakımdan da TAMP, ulusal düzeyde 28 , yerel düzeydeyse 26 hizmet üzerinden organize olarak her bir hizmetin sorumluluğunu ulusal ve yerel düzeyde bakanlık ve kamu kurum ve kuruluşlarına vermiştir (Tablo 2).

Hizmet gruplarının koordinasyonunu üstlenen ana çözüm ortakları, ilgili hizmetin ulusal seviyede esas sorumlusu olup aynı hizmet grubunda görevli destek çözüm ortaklarının da rollerini ve çalışmalarını belirlemektedir. Bu kapsamda ana çözüm ortakları ulusal seviyede; hizmet grubunun organizasyonundan, grubun hazırlık ve planlama çalışmalarının yönetiminden, grubun kapasitesinin geliştirilmesinden, kaynakların sağlanmasından, destek çözüm ortaklarını göreve çağırmaktan, finansal yönetimden, hazırlık protokollerinin oluşturulmasından, personel eğitiminden, diğer grupları desteklemekten, operasyonel dokümanları hazırlamaktan, koordinasyon ekiplerini belirlemekten, afet bölgesindeki çalışma esaslarını belirlemekten; yerel seviyede ise operasyonel tesis ve görevlileri belirlemekten, personel görevlendirmekten ve koordinasyonu sağlamaktan ve kaynakların etkin ve verimli bir biçimde kullanılmasını sağlamaktan sorumludur (TAMP, 2013, s. 15).

Hizmet gruplarında görevli destek çözüm ortakları ise, gerekli kaynakların temininden, operasyonlara destek vermekten, personel sürekliliği ve diğer grupları desteklemekten, hizmet grubu sorumlusunun hizmete ilişkin taleplerini yerine getirmekten sorumlu kılınmıştır (TAMP, 2013, s. 24).

\footnotetext{
${ }^{8}$ Uluslararası fonksiyonların yerine getirildiği iki hizmet grubu olan Uluslararası Destek ve İşbirliği Hizmet Grubuyla Ulusal ve Uluslararası Nakdi Bağış Hizmet Grubu, yerel düzeyde yer almamaktadır (TAMP, 2013, s.14).
} 
Afet Yönetimi ve Planlaması Perspektifinden Türkiye Afet Müdahale Planının Değerlendirilmesi

Tablo 2. Hizmet Grupları ve Ana Çözüm Ortakları (AFAD, 2018, s.39)

\begin{tabular}{|c|c|c|}
\hline Hizmet Grubu & $\begin{array}{l}\text { Ulusal Düzey Ana } \\
\text { Çözüm Ortağı }\end{array}$ & Yerel Düzey Ana Çözüm Ortağı \\
\hline Arama Kurtarma & AFAD & İl Afet ve Acil Durum Müdürlükleri \\
\hline Barınma & AFAD & İl Afet ve Acil Durum Müdürlükleri \\
\hline $\begin{array}{l}\text { Bilgi Yönetimi İzleme ve } \\
\text { Değerlendirme }\end{array}$ & AFAD & İl Afet ve Acil Durum Müdürlükleri \\
\hline Hizmet Grupları Lojistiği & AFAD & İl Afet ve Acil Durum Müdürlükleri \\
\hline Kaynak Yönetimi & AFAD & İ Afet ve Acil Durum Müdürlükleri \\
\hline KBRN & AFAD & İl Afet ve Acil Durum Müdürlükleri \\
\hline $\begin{array}{l}\text { Muhasebe, Bütçe ve Mali } \\
\text { Raporlama }\end{array}$ & AFAD & İl Afet ve Acil Durum Müdürlükleri \\
\hline Satın Alma ve Kiralama & AFAD & İl Afet ve Acil Durum Müdürlükleri \\
\hline Ulusal ve Uluslararası Nakdi & AFAD & Planın yerel düzeyi bulunmamaktadır. \\
\hline Uluslararası Destek ve İşbirliği & AFAD & Planın yerel düzeyi bulunmamaktadır. \\
\hline $\begin{array}{l}\text { Ayni Bağış Depo Yönetimi ve } \\
\text { Dağıtım }\end{array}$ & $\begin{array}{l}\text { Aile, Çalışma ve Sosyal } \\
\text { Hizmetler Bakanlığı }\end{array}$ & Sosyal Yardımlaşma ve Dayanışma Vakfı \\
\hline Psikososyal Destek & $\begin{array}{l}\text { Aile, Çalışma ve Sosyal } \\
\text { Hizmetler Bakanlığı }\end{array}$ & Aile, Çalışma ve Sosyal Hizmetler İI Müdürlükleri \\
\hline Altyapı & $\begin{array}{l}\text { Çevre ve Şehircilik } \\
\text { Bakanlığı }\end{array}$ & $\begin{array}{l}\text { Çevre ve Şehircilik İl Müdürlükleri / İller Bankası } \\
\text { Bölge Müdürlükleri }\end{array}$ \\
\hline Enkaz Kaldırma & $\begin{array}{l}\text { Çevre ve Şehircilik } \\
\text { Bakanlığı }\end{array}$ & Çevre ve Şehircilik İI Müdürlükleri \\
\hline Hasar Tespit & $\begin{array}{l}\text { Çevre ve Şehircilik } \\
\text { Bakanlığı }\end{array}$ & Çevre ve Şehircilik İı Müdürlükleri \\
\hline Enerji & $\begin{array}{l}\text { Enerji ve Tabii Kaynaklar } \\
\text { Bakanlığı }\end{array}$ & Özel Elektrik Dağıtım Şirketleri \\
\hline Gıda Tarım ve Hayvancılık & $\begin{array}{l}\text { Tarım ve Orman } \\
\text { Bakanlığı }\end{array}$ & İl Tarım ve Ormancılık Müdürlükleri \\
\hline Güvenlik ve Trafik & İçişleri Bakanlığı & İl Emniyet Müdürlükleri \\
\hline $\begin{array}{l}\text { Tahliye Yerleştirme ve } \\
\text { Planlama }\end{array}$ & İçişleri Bakanlığı & İl Göç Müdürlükleri \\
\hline Yangın & İçişleri Bakanlığı & Mahalli İdareler İI Müdürlükleri/Belediyeler \\
\hline Defin & İçişleri Bakanlığı & Mahalli İdareler İI Müdürlükleri/Belediyeler \\
\hline Zarar Tespit & $\begin{array}{l}\text { Hazine ve Maliye } \\
\text { Bakanlığı }\end{array}$ & İl Defterdarlıkları \\
\hline Sağlık & Sağlık Bakanlığı & İl Sağlık Müdürlükleri \\
\hline Haberleşme & $\begin{array}{l}\text { Ulaştırma ve Altyapı } \\
\text { Bakanlığı }\end{array}$ & Bilgi Teknolojileri Bölge Müdürlükleri \\
\hline Nakliye & $\begin{array}{l}\text { Ulaştırma ve Altyapı } \\
\text { Bakanlığı }\end{array}$ & Ulaştırma ve Altyapı Bölge Müdürlükleri \\
\hline Ulaşım Altyapı & $\begin{array}{l}\text { Ulaştırma ve Altyapı } \\
\text { Bakanlığı }\end{array}$ & Karayolları Bölge Müdürlükleri \\
\hline Teknik Destek ve İkmal & $\begin{array}{l}\text { Ulaştırma ve Altyapı } \\
\text { Bakanlığı }\end{array}$ & Karayolları Bölge Müdürlükleri \\
\hline Beslenme & Kızılay & Kızılay Bölge Müdürlükleri \\
\hline
\end{tabular}

Hizmet grupları, kendi iç organizasyonları bakımından incelendiğinde de, ulusal ve yerel seviye ayrımının, hizmet grubu organizasyonunda da kullanıldığı görülmektedir. Buna göre ulusal seviyede hizmet grupları koordinasyon ekipleri ve saha destek ekiplerinden oluşturulmaktayken, yerel düzeyde hizmet grubu organizasyonu operasyon ekipleri ve lojistik ekipleri şeklinde tanımlanmıştır (Ulusal Düzey Hizmet Grubu Plan Şablonu, 2014, s.8).

TAMP'ta tanımlanan bu organizasyon, işleyiş anlamında çeşitli seviyelere ayrılmıştır. Şöyle ki TAMP, tanımlanan müdahale seviyeleriyle, her durumda tüm kaynakların seferber edilmesi yerine, meydana gelen olayın etki derecesine göre hangi kaynakların kullanılacağına ilişkin bir projeksiyon sunmaktadır. 
Bahse konu müdahale seviyelendirmesine göre Seviye 1, yerel imkanların yeterli olduğu seviyeyi işaret emektedir. Bu seviyede İ Afet ve Acil Durum Yönetim Merkezi faaliyete geçmekte, AFAD ise gelişmeleri takip ederek intiyaç halinde kapasite yönlendirmektedir. Olay seviyesi Seviye 2 olarak tespit edildiğinde, II Afet ve Acil Durum Yönetim Merkezi, birinci grup destek illeri $^{9}$ ve ilgili arama kurtarma birlik müdürlüğü derhal harekete geçmektedir. Yine intiyaç duyulan hallerde AFAD tarafından ulusal kapasite yönlendirilebilmektedir. Ancak olay seviyesi 3 veya 4 olarak tespit edildiğinde, tüm hizmet grubu ana çözüm ortakları Afet ve Acil Durum Yönetim Merkezine çağrılmaktadır. Birinci ve ikinci grup destek iller afet bölgesine derhal hareket etmekte ve gerektiğinde ikinci grup destek iller yönetimi devralmaktadır. Ayrıca Seviye 4'te tüm ulusal kapasite müdahaleye katılmakta ve gerektiğinde uluslararası yardım çağrısı da yapılmaktadır (TAMP, 2013, s.8).

\section{TÜRKIYE AFET MÜDAHALE PLANINDA SORUN ALANLARINA İLIŞKIN BULGULAR}

Türkiye Afet Müdahale Planının afet yönetimi ve yönetim bilimi açısından incelenmesi iddiasını taşıyan bu çalışmanın içerisinde buraya kadar aktarılanlar değerlendirildiğinde afet yönetiminin, yönetim biliminin kendisine özel dinamikleri bulunan bir alt alanı olarak, bu dinamikler ve prensiplere uygun olacak şekilde, yönetim bilimi fonksiyonlarından ve bu fonksiyonların işleyişinden faydalanması gerektiği ve de temel olarak faydalandığı görülebilmektedir. Bu bakımdan afet yönetimi, afet kavramı içerisinde değerlendirilebilecek olay veya olayların öncesi, sırası ve sonrasını kapsayacak şekilde yönetim pratikleri geliştirmekte ve uygulamaktadır.

$\mathrm{Bu}$ kapsamda, afet yönetiminin belki de en önemli aracı konumundaki planlama ve organizasyonunun da, afet yönetiminin temel amaç ve hedefleri doğrultusunda oluşturulması ve kullanılması beklenmektedir. Türkiye'de de afet yönetimi, özellikle 1999 sonrası dönemde yaşanılan yeniden yapılanma sürecinde, özellikle planlama ve organizasyon konularına önem göstermiş ve afet planlaması ve organizasyonunda değişikliklere gidilmiştir. İşte Türkiye Afet Müdahale Planı da, bu süreç sonucunda müdahale aşamasını odak noktasına alan yeni bir ürün olarak ortaya çıkmıştır.

Türkiye Afet Müdahale Planının önceki kısımda amaç, kapsam ve yasal dayanaklar; planlar hiyerarşisi; planlama süreci; plan türleri; organizasyon yapısı ve hiyerarşik düzen ile organizasyonel yetki ve sorumluluklar konu başlıklarında yapılan analizi; Türkiye'nin olası bir afet durumunda bütün müdahale süreçlerini yürütme iddiasında olan bu planının eksik noktalarını da ortaya çıkarmıştır. Tespit edilen bu eksik noktalar, on bir farklı fakat birbirleriyle ilişkili sorun alanında değerlendirilebilmektedir.

TAMP'ın amaç, kapsam ve yasal dayanakları açısından analizi, esasen yasal dayanaklarıyla ilişkili iki sorun alanını ortaya çıkarmaktadır. Bunlardan ilki, TAMP'ta hem ulusal hem de yerel düzeyde kendisine görev verilen bazı kurumlara, başka kanun ve yönetmeliklerde de benzer konularda görev verilmiş olmasının doğurabileceği problemlerdir. Bilindiği üzere Türkiye'de afet yönetimi, "çok kanunlu" yasal altyapıya sahiptir. Bir başka ifadeyle Türkiye'de afet yönetimine ilişkin çalışmalar, birden fazla yasal dayanak çerçevesinde yürütülmektedir. Buna göre TAMP'ın yasal dayanağını oluşturan yönetmeliğin dayandığı 7269 sayılı Umumi Hayata Müessir Afetler Dolayısiyle Alınacak Tedbirlerle Yapılacak Yardımlara Dair Kanunla birlikte, doğal afetleri kapsamına dahil eden 7126 sayılı Sivil Savunma Kanunu, bahse konu çok kanunlu yönetim yapısının en bilinen örneklerini oluşturmaktadır. Ayrıca Türkiye Cumhuriyeti Anayasasının 119. Maddesine göre afetler, olağanüstü hal ilanına gerekçe olabildiğinden, olağanüstü halin ilan edilmesi durumunda 2935 sayılı Olağanüstü Hal

\footnotetext{
${ }^{9}$ Afet ve Acil Durum Müdahale Hizmetleri Yönetmeliğinin 4/i maddesine göre destek iller, AFAD tarafından olay bölgesine destek olmak üzere belirlenecek il gruplarını ifade etmektedir. TAMP içerisinde destek iller kapasite, bölgesel yeterlik ve uzaklık kriterleri açısından değerlendirilmektedir (Bkz. TAMP, 2013, s. 29-35) (Y.N.).
} 
Kanunu da, afet yönetiminin yasal dayanaklarına dahil olmaktadır. Ek olarak, 5393 sayılı Belediye Kanununun 14/a ve 53. Maddeleri, 5216 sayılı Büyükşehir Belediyesi Kanununun 7/u maddesi, 5302 sayılı İl Özel İdaresi Kanununun 6/b ve 69. Maddeleri de sırasıyla belediyeler, büyükşehir belediyeleri ve il özel idarelerine, kendi yetki ve sorumluluk alanlarında afet ve acil durumlara ilişkin planlama yapma görevi ve yetkisini vermektedir.

Burada sayılan bu çok kanunlu yapı, organizasyonel anlamda da bazı sorunları ortaya çıkarmaktadır. Şöyle ki, özellikle 7269,7126 ve 2935 sayılı kanunlar, aynı zamanda organizasyonel yapıları da beraberlerinde getirmektedir. Bu durumda, temel olarak aynı konu olduğu kabul edilebilecek bir duruma ilişkin olarak, hangi planlama ve organizasyon altında çalışılacağının tespit edilmesi sorunu da ortaya çıkmaktadır. Ayrıca, her ne kadar ilgili mevzuat koordinasyon ve işbirliğine atıfta bulunuyor olsa da, bahse konu koordinasyon ve işbirliğinin nası sağlanacağına ilişkin net bir bilgi veya talimat ortaya koymamaktadır (Şahin, 2014, ss.23-25).

TAMP'ın yasal dayanaklarına ilişkin bir diğer sorun alanıysa, ilgili mevzuatta tanımlanan yükümlülüklerin anayasal hak ihlali olup olmadığı sorunudur. Buna göre, TAMP'ın yasal altyapısını oluşturan Afet ve Acil Durum Müdahale Hizmetleri Yönetmeliğinin 33. Maddesi ile, 7269 sayılı kanunun 6 . Maddesinde doğrudan vatandaşlara yüklenen yükümlülüklerin, anayasada tanımlanan temel hak ve özgürlüklere aykırı olup olmadığının da, tartışılması gerekmektedir.

Temel hak ve özgürlükler (hürriyetler), anayasal güvence altında bulunan insan haklarıdır ve anayasal haklar olarak da bilinmektedir (Tanör ve Yüzbaşığlu, 2002, s. 131). Ancak bahse konu temel hak ve hürriyetler ve bunların kullanımı sınırsız olmayıp, toplumun varlığının ve sürekliliğinin sağlanabilmesi adına sınırlandırılmaları bir zorunluluk olarak değerlendirilmektedir (Kapani, 1981, s. 228). Bu bağlamda T.C. Anayasası da temel hak ve hürriyetlere bazı sınırlamalar getirmekte ve bu sınırlamaları olağan ve olağanüstü dönemler olmak üzere iki ayrı sistem altında değerlendirmektedir (Gözler, 2011, s. 123).

$\mathrm{Bu}$ bağlamda, olağan dönemlerde yürütülecek sınırlama rejimi T.C. Anayasası 13. Maddesinde, olağanüstü dönemlerde yürütülecek sınırlama rejimiyse T.C. Anayasası 15. Maddesinde düzenlenmektedir. Olağan dönemlerde Anayasanın 13. Maddesine göre temel hak ve hürriyetlerin, özlerine dokunulmadan, yalnızca Anayasanın ilgili maddesinde belirtilen sebeplerle ve ancak kanunla sınırlanabileceği hükme bağlanmıştır ${ }^{10}$.

İlgili madde hükmünden de anlaşılabileceği üzere anayasa, temel hak ve hürriyetlerin sınırlandırımasına bazı sınırlamalar getirmiştir. Buna göre temel hak ve hürriyetler ancak kanunla ve ilgili anayasa maddesindeki sebeplere dayanılarak sınırlandırılabilmektedir. Örneğin Anayasanın 23. Maddesinde güvence altına alınan vatandaşın yurt dışına çıkma ve seyahat hürriyetleri sırasıyla, vatandaşlık ödevi ya da ceza soruşturması veya kovuşturması; suç soruşturma ve kovuşturması sebeplerine dayanılarak ve kanundan alınan yetkiyle sınırlandırılabilecektir (Gözler, 2011, ss.125-126).

Olağanüstü dönemlerdeyse Anayasa, temel hak ve hürriyetlerin daha aşırı bir şekilde sınırlandırımasına ve hatta kullanımlarının durdurulmasına olanak tanımaktadır (Gözler, 2011, s. 134). Buna göre "savaş, seferberlik veya olağanüstü hallerde, milletlerarası hukuktan doğan yükümlülükler inlâl edilmemek kaydıyla, durumun gerektirdiği ölçüde temel hak ve hürriyetlerin kullanılması kısmen veya tamamen durdurulabilir veya bunlar için Anayasada öngörülen güvencelere aykırı tedbirler alınabilir" (T.C. Anayasası, Md. 15/1).

\footnotetext{
${ }^{10}$ Bu çalışma bir anayasa hukuku çalışması değildir. Dolayısıyla çalışmanın temel amacı dışına çıkmadan, esasen çok detayı bir şekilde incelenmesi gereken anayasal hak ve özgürlüklere ilişkin bu konunun incelenmesinde bazı detaylar inmal edilmiştir (Y.N.).
} 
Anayasanın "olağanüstü hal yönetimi" başlıklı 119. Maddesine göre doğal afetler veya tehlikeli salgın hastalıklar, olağanüstü halin ilan edilme gerekçeleri arasında sayılmaktadır. Bu bağlamda, ilgili maddede sayılı gerekçelere bağlı olarak ilan edilecek olağanüstü hal, bazı sonuçlar doğuracaktır. Yine Anayasa madde 119/5'te sayılan bu sonuçlara göre vatandaşlara para, mal ve çalışma yükümlülükleri getirilebilmekte ve temel hak ve hürriyetler 15. Maddedeki ilkeler doğrultusunda sınırlandırılabilmekte veya geçici olarak durdurulabilmektedir.

Anayasanın amir hükümlerinin de açıkça gösterdiği üzere vatandaşlara para, mal ve çalışma yükümlülüklerinin getirilebilmesi, ancak olağanüstü halin ilanıyla mümkün olabilmektedir. Bu husus çalışma konusu bakımından değerlendirildiğinde de, özellikle 7269 sayılı kanunun 6 . Maddesiyle mülki idare amirlerine verilen ve vatandaşlara para, mal ve çalışma yükümlülüğü getirmeye ilişkinin yetkinin Anayasaya uygunluğunun tartışılması gerekecektir. Nitekim Kuzu (1993, ss.191-192) ilgili kanun hükmünün geçerliliğinin tartışmaya açık olduğunu ifade ederken Gözler (2011, s. 384) 7269 sayılı kanunla birlikte benzeri hükümler içeren kanunların Anayasaya aykırı olduğunu ifade etmektedir. Bu durum da, özellikle müdahale aşamasında ortaya çıkabilecek kaynak intiyacının, TAMP kapsamında gerek zorunlu çalıştırma gerekse el koyma marifetiyle giderilmeye çalışılmasında hukuki sorunların ortaya çıkmasına neden olabilecektir.

TAMP'ın planlar hiyerarşisi açısından analizi de, temel olarak iki sorun alanına işaret etmektedir. Bunlardan birincisi, önceki başlıkta aktarılan öncüllük ve ardıllık ilişkisi tamamlanmadan müdahale planının hazırlanmış olmasıyla ilgilidir. İlgili kısımdan da hatırlanacağı üzere TAMP taktik seviye bir plan olarak, hem dikey ölçekte hem de yatay ölçekte, afet yönetimi içerisinde yer alması gereken diğer planlarla ilişkili şekilde konumlandırılmıştır. Buna göre TAMP, kendisinden bir üst seviye olan stratejik seviyede Türkiye Afet Yönetimi Strateji Belgesinin uygulama aracı konumunda olmakla birlikte, bu konumunu hem risk ve zarar azaltma hem de iyileştirme planlarıyla da paylaşmak durumundadır.

Ancak TAMP'ın planlar hiyerarşisi açısından yapılan analizleri, hem stratejik seviyede, hem risk ve zarar azaltma aşamasında hem de iyileştirme aşamasında yapılan çalışmaların henüz tamamlanmadığını, bu bağlamda da TAMP'ın kendi öncülü olması gereken plan ve stratejilerden yoksun bir şekilde hazırlandığını ortaya çıkarmaktadır.

Bilindiği üzere strateji kavramı, belirlenmiş amaçların başarılabilmesi için izlenecek yol ve yöntemleri ifade etmektedir (Çevik, 2001, s. 310; Tunçer, 2012, s. 364). Strateji kavramıyla ilişkili olarak stratejik yönetim kavramıysa, geleceğe dönük amaç ve hedeflerin belirlenmesini ve bunlara ulaşılabilmesi için gereken işlemlerin tespit edilmesini ifade etmektedir (Aktan, 2003, s. 68; Tunçer, 2012, s. 366).

Çalışma içerisinde değinildiği üzere planlar, yerine getirdikleri fonksiyonlar bakımından sınıflandırılabilmektedir. Buna göre taktik planlar ağırlıklı olarak orta seviyede olup, stratejik planların amaçlarına ulaşabilmesi için hazırlanan planlar olarak tanımlanırken; operasyonel planlar da bir işin veya görevin yerine getirilebilmesi için hazırlanan alt seviye planlar olarak tanımlanmaktadır. Bu anlamda, burada ifade edilen planlar hiyerarşisinin en üstünde konumlanan stratejik planlar da, ayrıntılar yerine hedeflere ve geleceğe odaklanan, bir başka ifadeyle neyin yapılması gerektiğinin işaret edildiği planlar olarak tanımlanmaktadır (Tortop vd., 2010, s. 222).

Önceki bölümlerde de değinildiği üzere bu yönde bir stratejik yaklaşım, afet yönetimi için de kullanılabilmektedir. Bu bakımdan, hele ki Türkiye gibi, zarar görebilirliği ve afetselliği yüksek 
ülkelerde, ulusal ölçekte tanımlanmış ve uzun vadeli politikaların yer aldığı ulusal afet yönetimi stratejilerinin önemi daha fazla ortaya çıkmaktadır. Nitekim Onuncu Kalkınma Planının afet yönetimine iliş̧kin başlıkları incelendiğinde de benzer vurguların yapıldığı görülebilmektedir. Bu bakımdan Onuncu Kalkınma Planı; toplumun afet risklerine karşı daha dirençli hale getirilmesini (md. 1060) ve "afetler konusunda risk azaltma, hazırlık, müdahale ve afet sonrası iyileştirme çalışmalarının bir bütünlük içinde yürütülebilmesi için kılavuz olarak kullanılabilecek Ulusal Afet Stratejisinin hazırlık çalışmaları devam ettiği"ni (md. 1061) vurgulamakta ve "makroekonomik, sektörel ve mekânsal planlama süreçlerinde afet risk ve zararlarının dikkate alınması; afetlere karşı toplumsal direncin ve bilinç düzeyinin artırıması; afetlere dayanıklı ve güvenli yerleşimler oluşturulması"nı (md. 1063) temel amaç olarak tanımlamaktadır (Kalkınma Bakanlığı, 2013, s.140). Bu nedenle, Türkiye'nin afet yönetimiyle ilgili yol haritasından yoksun hazırlanan TAMP'ın stratejik bir yaklaşımla uygulanabilirliği tartışma konusu olacaktır.

Planlar hiyerarşisi içerisindeki diğer sorun alanıysa, risk ve zarar azaltma stratejisi ve planlaması tamamlanmadan, bir müdahale planı olan TAMP'ın hazırlanmış olmasının doğurabileceği sorunlara ilişkindir. Bu noktada risk yönetimi süreciyle müdahale süreci arasındaki ilişkiyi iki boyutlu olarak değerlendirmek doğru olacaktır. Bu boyutlardan birincisi, risk azaltma çalışmaları neticesinde müdahale çalışmalarının daha kolay, etkin ve verimli bir biçimde gerçekleştirilebileceği iddiasıdır. Nitekim Kadıoğlu (2011, ss. 67-92) da riski; tehlike, maruziyet ve savunmasızlığın bir bileşkesi olarak değerlendirmekte ve bileşenlerin her biri için yürütülecek iyileştirme çalışmaları sonucunda risk miktarının azalacağını; bir diğer ifadeyle risk azaltmadaki gerçek hedefin riskin kabul edilebilir seviyeye indirgenmesi olduğunu ifade etmektedir. Bu yorumdan hareketle müdahale planlamasının, ancak risk gerçekleştiğinde meydana gelecek sonucun yönetilebilir bir ölçüte indirgenmesi sonrasında yapılması gerektiği sonucu çıkarılabilmektedir.

Risk yönetimi süreciyle müdahale süreci arasındaki ilişkinin bir diğer boyutu da, risklerin tespit edilmesidir. Doğaldır ki riskin tespiti ve analizi, riski oluşturan bileşenlerin tespiti ve analiziyle mümkün olmaktadır. Bir başka ifadeyle kayıp ihtimalinin somutlaştırılması; öncelikle tehlikelerin, tehlikelere maruz değerlerin ve aynı değerlerin zarar görebilme intimallerinin ortaya çıkarılmasıyla mümkün olacaktır. Buna göre zarar verme potansiyeline sahip olan tüm durumların, zarar görebilecek tüm varlıkların ve bu varlıkların ne kadar zarar görebilir olduklarının belirlenmesi gerekmektedir (Kadıoğlu, 2011, ss. 68-84). Risk analizi süreci olarak isimlendirilebilen bu süreç, neyin, nerede ve ne kadar zarar verebileceğine ilişkin bir projeksiyon çizilmesine yardımcı olmaktadır.

Burada kısaca aktarılmaya çalışılan her iki boyut birlikte değerlendirildiğinde risk ve zarar azaltma stratejisinin hem meydana gelecek olayı yönetilebilir bir boyuta indirgediği hem de hangi olayın hangi ölçekte ve nerede meydana gelebileceğine dair yol gösterici olduğu görülebilmektedir. Bu veriler üzerine oluşturulan müdahale planlarının da, özellikle operasyonel seviyede daha somut bir şekilde kurgulanabileceği iddia edilebilecektir (Tablo 3). 
Tablo 3. Hatay İlinin Hasar Dağılımı ve Etkilenen Kişi Sayısı (TAMP-HATAY, 2019, s. 35)

\begin{tabular}{|c|c|c|c|c|c|c|c|c|c|c|c|}
\hline İlçe & $\begin{array}{l}\text { Bina } \\
\text { Sayısı }\end{array}$ & $\begin{array}{c}\text { Az } \\
\text { Hasarlı } \\
\text { Bina }\end{array}$ & $\begin{array}{c}\text { Orta } \\
\text { Hasarlı } \\
\text { Bina }\end{array}$ & $\begin{array}{c}\text { Ağır } \\
\text { Hasarlı } \\
\text { Bina }\end{array}$ & $\begin{array}{l}\text { Yıkık } \\
\text { Bina }\end{array}$ & $\begin{array}{c}\text { Etkilenen } \\
\text { Toplam } \\
\text { Nüfus }\end{array}$ & $\begin{array}{l}\text { Ayakta } \\
\text { Tedavi }\end{array}$ & $\begin{array}{l}\text { Hafif } \\
\text { Yaralı }\end{array}$ & $\begin{array}{l}\text { Ağır } \\
\text { Yaralı }\end{array}$ & $\begin{array}{c}\text { Can } \\
\text { Kaybı }\end{array}$ & $\begin{array}{c}\text { Geçici } \\
\text { Barınma } \\
\text { (Kişi } \\
\text { Sayısı) }\end{array}$ \\
\hline Altınözü & 15.685 & 1.494 & 2.117 & 4.927 & 4.587 & 60.743 & 5674 & 2.101 & 1.370 & 731 & 27.727 \\
\hline Antakya & 57.891 & 323 & 614 & 4.405 & 52.133 & 360.652 & 99.454 & 36.495 & 24.808 & 13.231 & 342.315 \\
\hline Arsuz & 22.777 & 3.539 & 4.242 & 6.167 & 1.358 & 82.498 & 1.824 & 689 & 394 & 210 & 16.606 \\
\hline Belen & 8.947 & 1.005 & 1.419 & 3.101 & 1.706 & 30.842 & 1.824 & 680 & 429 & 229 & 11.035 \\
\hline Defne & 22.070 & 57 & 119 & 1.180 & 20.645 & 140.097 & 39.580 & 14.522 & 9.879 & 5.269 & 135.201 \\
\hline Dörtyol & 26.583 & 4.447 & 3.831 & 2.937 & 228 & 118.761 & 511 & 194 & 85 & 45 & 7.967 \\
\hline Erzin & 13.026 & 1.891 & 1.293 & 659 & 25 & 41.290 & 66 & 24 & 8 & 4 & 1.309 \\
\hline Hassa & 14.190 & 2.412 & 2.341 & 2.271 & 275 & 54.130 & 426 & 162 & 81 & 43 & 5.388 \\
\hline Kumlu & 3.562 & 157 & 240 & 806 & 2.109 & 13.060 & 2.363 & 870 & 584 & 311 & 9.215 \\
\hline Kırıkhan & 24.106 & 715 & 1.065 & 3.673 & 17.454 & 108.918 & 25.613 & 9.408 & 6.369 & 3.397 & 91.905 \\
\hline Payas & 7.127 & 1.216 & 1.145 & 1.036 & 107 & 40.434 & 266 & 101 & 49 & 26 & 3.635 \\
\hline Reyhanlı & 17.982 & 2.451 & 2.937 & 4.553 & 2.899 & 90.758 & 4.312 & 1.602 & 1.017 & 542 & 24.891 \\
\hline Samandağ & 23.799 & 385 & 682 & 3.818 & 18.382 & 117.770 & 28.308 & 10.402 & 7.035 & 3.752 & 102.573 \\
\hline Yayladağı & 9.684 & 416 & 655 & 2.240 & 5.737 & 27.347 & 5.061 & 1.863 & 1.250 & 667 & 19.706 \\
\hline İskenderun & 37.494 & 5.472 & 6.857 & 11.158 & 3.048 & 246.207 & 7.455 & 2.806 & 1.661 & 886 & 60.080 \\
\hline Toplam & 304.923 & 25.980 & 29.557 & 52.931 & 130.693 & 1.533 .507 & 222.737 & 81.919 & 55.019 & 29.343 & 859.553 \\
\hline
\end{tabular}

Örneğin, Tablo 3'te yer alan Hatay iline ait veriler incelendiğinde, mevcut durumda 7,5 büyüklüğünde gerçekleşebilecek bir depremin olası sonuçlarına göre, Antakya ilçesinde bulunan 57.891 binanın 57.475 'inin çeşitli ölçülerde hasar göreceği, bu binaların 52.133'ününse yıkılacağı öngörülmektedir. Ayrıca 1.609 .856 kişi olan Hatay nüfusunun 1.533.507'sinin bu depremden etkileneceği, bunların da yaklaşık 30.000'inin hayatını kaybedeceği tahmin edilmektedir (TAMP-HATAY, 2019, ss.34-35).

Eski tarihli olmakla birlikte, İstanbul için 2009 yılına ait veriler incelendiğinde, yapılan tahminlere göre $3.500-5.000$ binanın çok ağır hasar göreceği, $20.000-30.000$ binanın ağır hasar, 90.000 - 110.000 binanın orta seviyede hasar göreceği; can kaybının 15.000 35.000 arasında olacağı ve acil barınma ihtiyacının ise yaklaşık 500.000 hane olacağı tahmin edilmektedir (İstanbul Büyükşehir Belediyesi, 2009a, s.249). Buna göre can kaybı İstanbul nüfusunun \%0.1 - \%0.2'sine; kullanılamayacak binalar ise toplam yapı stokunun \%10 - \%15’ine tekabül etmektedir (İstanbul Büyükşehir Belediyesi, 2009b, s.14).

Yine İstanbul için, 2000 yılı sonrasında yapılan binaların olası hasarlarını tahmin etmek amacıyla yapılan bir araştırmanın sonuçları da, çeşitli yöntemlerle yapılmış modelleme neticelerine göre, İstanbul ilinde 2000 yılından sonra inşa edilmiş toplam 180.000 binanın \%10 - \%24'ünün orta ve üzeri hasar görmesinin beklendiğini ortaya çıkarmaktadır (Hancılar vd., 2017). 
Deprem senaryoları üzerinden aktarılan verilerin de gösterdiği üzere, sadece müdahale süreçlerine odaklanan planlama yaklaşımının, örnek senaryolar karşısında çok da etkin sonuçlar doğurması beklenmemelidir. Bu nedenle, riskin yönetilebilir bir seviyeye indirilmesiyle birlikte riskin somutlaştırılması; bir başka ifadeyle riskin nerede ve ne kadar zarar verebileceğinin de bilinmesi, müdahale planlaması açısından son derece önemlidir. Öncül strateji olarak risk ve zarar azaltma stratejilerinden yoksun hazırlanan TAMP'ın, örnek senaryolarda gösterilenlere benzer durumlar karşısında, başarılı olacağı iddia edilemeyecektir.

TAMP, planlama süreci bakımından incelendiğinde de, iki temel sorun alanı olduğu görülmektedir. Bu sorun alanlarından birincisi, yönetimin fonksiyonları arasındaki işlem sırasının bozularak planlamanın yerine organizasyonel süreçlerin öncelikle tanımlanması; ikincisiyse tek bir olaydan hareket edilerek planlama yapılmasıdır. Nitekim önceki bölümde ifade edildiği üzere 2011 yılında meydana gelen Van Depremi ve bu depremden öğrenilenlere dayandırılan TAMP süreci, planlama yerine organizasyonun kurulmasıyla başlamaktadır.

Çalışmanın ilgili bölümünde açıklandığı üzere yönetim, beş temel fonksiyon üzerinden incelenmekte ve bu fonksiyonlar arasında da belirli bir sıralama bulunmaktadır. Buna göre, planların uygulama araçları olarak organizasyonların, yönetim faaliyeti sonucunda ulaşılmak istenen amaca ulaşmakta kullanılacak işlerin planlanması sonrasında kurulması gerekmektedir. Ancak TAMP'ın planlama süreci incelendiğinde, sürecin organizasyon aşamasıyla başladığı görülebilmektedir.

Nitekim, TAMP'ın "Plan Hazırlama Süreci” başlıklı kısmında yer alan "organizasyon süreci" alt başlığında da, öncelikle hizmet gruplarının oluşturulması, sonrasındaysa hizmet grubu süreç analiziyle yapılacak hizmetlerle ilgili olarak afet öncesi, sırası ve sonrasındaki görev ve çalışmaların belirlenmesi sürecinin yürütüldüğü belirtilmektedir (TAMP, 2013, s.5). Buna göre, afet yönetiminin müdahale aşamasına ilişkin yapılması gereken işlerin, organizasyon süreci sonrasında tespit edildiğini; bu yaklaşımın da yönetim biliminin fonksiyonel işleyişine aykırı olduğu anlaşılabilmektedir. Bu aykırılık; planlar hiyerarşisine ilişkin analizinde de ifade edildiği üzere TAMP'ın, stratejik ve taktik öncüllerinden yoksun olmasıyla açıklanabileceği gibi; TAMP'ın hazırlanma sürecindeki dayanak noktasının Van Depremi olmasıyla da açıklanabilecektir.

Türkiye'nin doğusunda bulunan Van ilinde, 23 Ekim 2011 ve 9 Kasım 2011 tarihlerinde meydana gelen, sırasıyla 7.0 Mw ve $5.7 \mathrm{Mw}$ büyüklüğündeki depremler sonucunda toplam 644 kişi hayatını kaybetmiş, 1966 kişi de yaralanmıştır (AFAD, 2019b). Van ili genelinde, yapı stokunun da etkisiyle yıkıcı etki yaratan depremler, 36.203 konut ve 2.884 işyerinin yıkılmasına veya ağır hasar görmesine; 18.181 konut ve 3.907 işyerinin orta derece hasar görmesine; 58.374 konut ve 7.992 işyerininse hafif hasar görmesine neden olmuştur (AFAD, 2014, s.23).

Her ne kadar, Van'da meydana gelen depremler sonucunda yapısal hasar yüksek olmuşsa da, gerek ölü ve yaralı sayıları gerekse depremlerin aletsel yoğunlukları dikkate alındığında, 2011 yılında Van'da meydana gelen depremlerin bölgesel bir olay olduğu iddia edilebilecektir. Örneğin 17 Ağustos 1999 yılında meydana gelen Gölcük (Marmara) Depremi, şiddeti bakımından çok geniş bir alanı etkilemişken (10 il doğrudan etkilenmiştir) 2011 Van Depreminin şiddet etki alanı, büyük oranda Van iliyle sınırlı kalmıştır (Harita 1). 


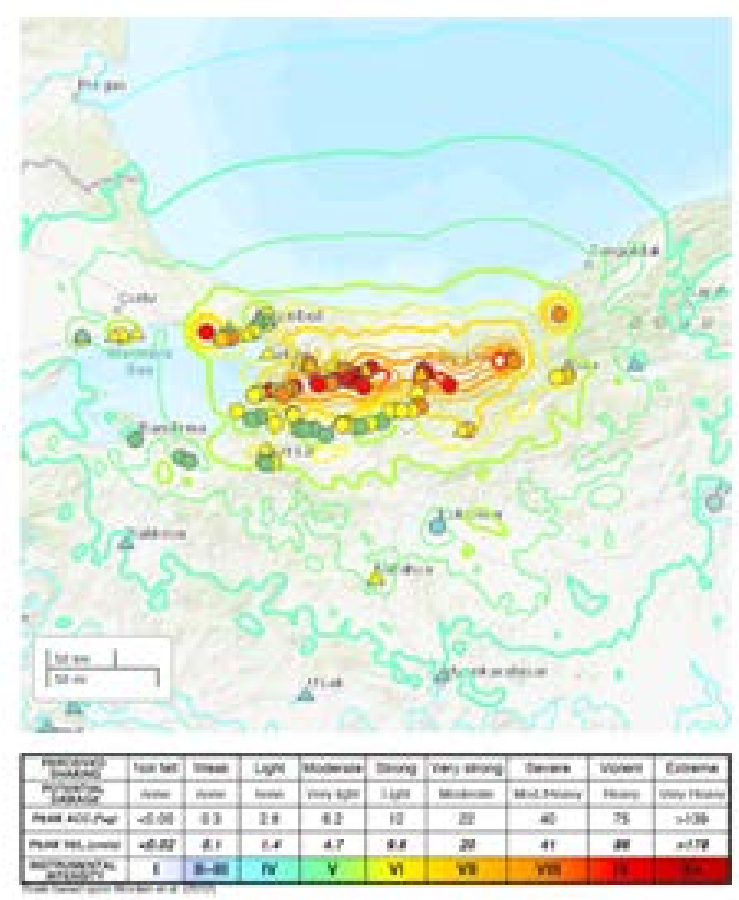

17 Ağustos 1999 Marmara Depremi Şiddet Haritası

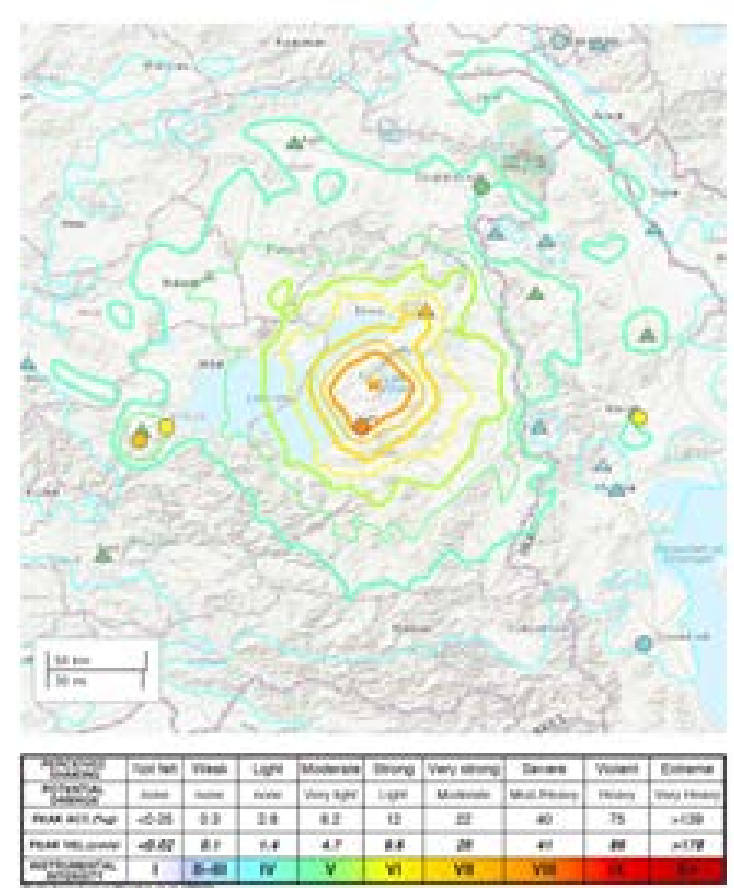

23 Ekim 2011 Van Depremi Şiddet Haritası

Harita 1. 1999 Marmara Depremi ve 2011 Van Depremi Şiddet Haritası

Kaynak: USGS, 2019a; USGS, 2019bAyrıca, Harita 1'de gösterilen veriler, depremlerin meydana geldiği nüfuslarla birlikte de yorumlanabilecektir. Şöyle ki, 1999 yılında meydana gelen Marmara Depreminden yaklaşık olarak 16 milyonluk bir nüfus etkilenmişken (Tablo 4), TÜIK verilerine göre 2011 yılındaki Van nüfusu 1.022.532 kişidir (TÜİK, Adrese Dayalı Nüfus Kayıt Sistemi, 2019).

Tablo 4. 1999 Marmara Depreminden Etkilenen Nüfusa İlişkin Veriler (Afet İşleri Genel Müdürlüğü, 2000, s. 211)

\begin{tabular}{|l|c|c|c|c|c|c|c|}
\hline \multicolumn{1}{|c|}{ il Adı } & $\begin{array}{c}\text { Toplam } \\
\text { Nüfus }\end{array}$ & $\begin{array}{c}\text { Sehir } \\
\text { Nüfusu }\end{array}$ & $\%$ & $\begin{array}{c}\text { Köy } \\
\text { Nüfusu }\end{array}$ & $\%$ & $\begin{array}{c}\text { Yüzölçümü } \\
\mathbf{( k m}^{2} \mathbf{)}\end{array}$ & $\begin{array}{c}\text { Nüfus } \\
\text { Yoğunluğu }\end{array}$ \\
\hline Bilecik & 192.060 & 116.004 & 60 & 76.056 & 40 & 4.302 & 45 \\
\hline Bolu & 553.022 & 265.052 & 48 & 287.970 & 52 & 10.887 & 51 \\
\hline Bursa & 1.958 .529 & 1.484 .838 & 76 & 473.691 & 24 & 10.422 & 188 \\
\hline Eskişehir & 660.843 & 518.643 & 78 & 142.200 & 22 & 13.841 & 48 \\
\hline İstanbul & 9.198 .809 & 8.506 .026 & 92 & 692.783 & 8 & 5.196 & 1.770 \\
\hline Kocaeli & 1.177 .379 & 629.333 & 53 & 548.046 & 47 & 3.612 & 326 \\
\hline Sakarya & 731.800 & 331.431 & 45 & 400.369 & 55 & 4.838 & 151 \\
\hline Tekirdağ & 567.396 & 358.878 & 63 & 208.518 & 37 & 6.313 & 90 \\
\hline Yalova & 163.916 & 110.106 & 67 & 53.810 & 33 & 848 & 193 \\
\hline Zonguldak & 612.722 & 239.186 & 39 & 373.536 & 61 & 3.304 & 185 \\
\hline TOPLAM & $\mathbf{1 5 . 8 1 6 . 4 7 6}$ & $\mathbf{1 2 . 5 5 9 . 4 9 7}$ & - & $\mathbf{3 . 2 5 6 . 9 7 9}$ & - & $\mathbf{6 4 . 3 6 5}$ & - \\
\hline
\end{tabular}

Kısaca açıklanmaya çalışılan verilerin de gösterdiği üzere AFAD'ın, TAMP'a dayanak olarak 2011 Van Depremini göstermiş olması, Türkiye'nin afetselliği de düşünüldüğünde, TAMP'tan beklenen sonuçlara ulaşılamamasına sebep olabilecektir. Bir başka ifadeyle bir milyonun biraz üzerinde nüfusa sahip, yapı kalitesi kötü ve büyük oranda tek bir ili etkilemiş olan bir depremden öğrenilenlere dayandırılan TAMP'ın, İstanbul'da beklenen veya 1999 yılındakine benzer ölçülerdeki bir deprem karşısında başarısı tartışmaya açıktır. 
Ek olarak Türkiye, bilindiği üzere deprem dışında birçok doğal ve insan kaynaklı afete maruz bir ülkedir. Bu nedenle, sadece depreme dayandırılan ve depreme müdahale odaklı planlama modellerinin Türkiye'nin afetselliğine bağlı bütün intiyaçlarını karşılayıp karşılayamayacağı da yine tartışmaya açık olacaktır.

TAMP, organizasyon yapısı ve hiyerarşik düzen ile organizasyonel yetki ve sorumluluklar ekseninde incelendiğindeyse; birbirleriyle ve doğaldır ki planlama aşamasıyla da ilişkili beş temel sorun alanı olduğu görülmektedir. Ancak, bu sorun alanlarına ilişkin değerlendirmelerden önce, olay komuta sisteminin yapısı ve işleyişinin incelenmesi gerekecektir. Kısaca aktarılması gerekirse olay komuta sistemi, daha önce meydana gelen olaylardan edinilen tecrübeler ve ortaya çıkan intiyaçlardan doğmuş bir çözümü ifade etmektedir.

Kadıoğlu'na (2011, s.115) göre afet yönetiminin müdahale süreçlerinde yaşanan aksaklıklar ve sorunlar; kurumlar arasında dil ve fikir birliğinin sağlanamaması, olaya bağlı genişleme veya küçülme kapasitelerinin bulunmaması, üzerinde uyum sağlanmış ve kullanılabilir müdahale planlarının olmayışı, iletişimin standardize edilmemiş olması, müdahale için önceden planlanmış ve hazırlanmış tesislerin eksikliği, kaynak yönetimi stratejisinin olmaması ve önceden planlı bir organizasyonun olmaması nedeniyle hiyerarşik düzenin sağlanmamasına bağlıdır.

Nitekim olay komuta sistemi de, yukarıda sayılan bu sorunlara benzer sorunların yaşandığı 1970 Güney Kaliforniya Orman Yangınları sonrasında, bu ve benzer sorunlara çözüm üretebilmek amacıyla ortaya çıkmıştır. Buna göre ortak bir terminoloji ve organizasyonun eksikliği, sahadaki ve kurumlar arasındaki iletişim zayıflığı, birleşik planlamanın yetersizliği, doğru ve zamanında bilgi akışının sağlanamaması, yetersiz kaynak yönetimi ve yetersiz bilgi akışına bağlı olarak geleceğe dönük kısıtlı tahmin olanaklarından kaynaklanan sorunlara çözüm üretebilmek amacıyla; tekbir olaydan birçok kurumun dahil olduğu müdahale süreçlerini karşılayabilen, olayın boyutuna bağlı olarak genişleyebilen, bütün olaylarda kullanılabilen, yeni teknolojilerle uyumlu, terminoloji organizasyon ve prosedür anlamında standardize edilmiş, mevcut prosedürlerle uyumlu sürdürülmesi ve öğretilmesi kolay olan olay komuta sistemi kurgulanmıştır (Canton, 2007, ss.267-268).

Her ne kadar günümüzde, tek ve standart bir olay komuta sistemi organizasyonunun varlığı söz konusu olmasa da, '70'li yıllarda oluşturulan orijinal olay komuta sistemi, yapısı itibariyle bilinen beş temel fonksiyondan oluşmaktadır: Komuta, operasyon, planlama, lojistik, finans ve idare fonksiyonları (Canton, 2007, s271). Kadıoğlu'na (2011, s. 117) komuta fonksiyonu yöneten, operasyon fonksiyonu yapan, planlama fonksiyonu düşünen, lojistik fonksiyonu temin eden ve finans ve idare fonksiyonu da satın alan ve ödeyen konumundadır.

Kadıoğlu'nun değerlendirmelerinden hareketle olay komuta sisteminin, bünyesindeki kurum sayısından bağımsız olarak, tek bir organmış gibi hareket etmesi beklenebilecektir. Şöyle ki, esas olarak sahayı sahada yönetmek üzere tasarlanmış bir araç olarak olay komuta sistemi, yukarıda sayılan fonksiyonlarıyla temel olarak operasyonel planlamayı, operasyonel lojistiği ve operasyonel finansı yürütmek üzere tasarlanmıştır. Nitekim Canton (2007, s.275) da olay komuta sisteminin operasyonel bir araç olarak başarılı olmasına rağmen afet yönetiminin müdahale süreçlerinin koordinasyonu anlamında, çoklu kurum koordinasyon sistemleri gibi (multi-agency coordination system - MACS) sistemlerin kullanılması gerektiğini savunmaktadır.

Bu bakımdan taktik seviye bir plan olarak TAMP'ın, operasyonel seviyede bir organizasyona sahip olmasının özellikle saha uygulamalarının koordinasyonu anlamında bir takım sorunlar üretmesinin olası olduğu değerlendirilmelidir. Bu bağlamda, özellikle ulusal seviyede TAMP 
organizasyonunun yine olay komuta sistemine benzeyen fakat hizmetin sahada yürütülmesi yerine sahada hizmet yürüten birimlerin koordinasyonu amacıyla tasarlanmış, ulusal seviye intiyaçlarına uygun organizasyonel yapılarla oluşturulması gerekliliği, tartışmaya açılmalıdır.

Her ne kadar ulusal seviyede olay komuta sistemi yerine çoklu kurum koordinasyon sistemlerinin kullanımının tartışılması gerektiği ifade edilse de, TAMP'ın mevcut organizasyon yapısı üzerinden yapılan analizler bağlamında tespit edilen beş temel sorun alanının da, ayrıca incelenmesi gerekmektedir. Bunlardan birincisi, bir ara plan formatı olarak, olay komuta sistemi içerisinde servis planlarının tanımlanmamış olmasıdır.

Halbuki servis, Afet ve Acil Durum Müdahale Hizmetleri Yönetmeliğinin 4/o maddesine göre "müdahale organizasyonu içerisinde yer alan hizmet gruplarının bağlı olduğu ana yönetim birimleri" olarak tanımlanmakta ve TAMP'ın içerisinde de müdahale yönetiminin temel birimleri olarak gösterilmektedir. Örneğin müdahale servisi için TAMP, "müdahale organizasyonunda, temel birim olarak planı uygulamaya koyan servistir" tanımlamasını yapmaktadır (TAMP, 2013, s. 11).

Önceki bölümde ifade edildiği üzere TAMP'ın organizasyonel yapısından, sistemin hizmet grupları üzerinden işletilmek istendiği anlaşılabilmektedir. Ancak yönetim biliminin organizasyon süreçleri tekrar incelendiğinde, planlama süreci sonucunda belirlenen işlerin gruplandırımasının, organizasyonun önemli bir aşaması olduğu görülebilecektir. Bu bağlamda da TAMP, klasik olay komuta sistemi düzeni içerisinde hizmet gruplarını, komutaya bağlı dört ana iş grubu altında toplamıştır. Buna göre TAMP, doğrudan sahada yürütülecek arama kurtarma, barınma ve beslenme, enkaz kaldırma, defin vb. işleri bir grup, bilgi toplama ve analize yönelik işleri bir grup, lojistik işleri bir grup ve finansal işleri yine bir grup olarak değerlendirmiş; bu işlerde görev alacak hizmet gruplarını da servis adını verdiği bu üst grupların altında konumlandırmıştır. Ancak, ifade edildiği üzere, birden fazla hizmet grubundan oluşan bu servislerin nasıl yönetileceğini ve koordine edileceğini tanımlamamıştır.

Örneğin meydana gelen bir deprem sonrasında bir arama ve kurtarma faaliyetinin icra edilmesi gerektiği değerlendirildiğinde; planlamaya göre konuşlanma noktasından hareket ederek arama kurtarma çalışmasının yapılacağı alana intikal etmesi gereken arama ve kurtarma ekibinin, bu işi yerine getirebilmesi için, çok basit bir yaklaşımla kendisi haricindeki en az üç hizmet grubuyla daha birlikte çalışması gerekecektir. Şöyle ki, ilgili arama kurtarma ekibinin ulaşımı, güvenliği ve çalışmaları sonucunda ulaştığı yaralıların tedavisi, başka hizmet gruplarının görev alanına girmektedir. Ancak TAMP, aynı servis içerisinde organize edilmiş hizmet gruplarının aralarındaki koordinasyona net bir çözüm üretemediği gibi, diğer servislerle olan koordinasyon için de yine net bir çözüm ortaya koyamamaktadır.

Bu bakımdan; operasyon, planlama, lojistik veya finans servisi fark etmeksizin, aynı üst fonksiyon için çalışan ve birden fazla kurumun vücuda getirdiği hizmet gruplarının da nasıl koordine edileceğinin planlanması, operasyonel başarıyı arttıracağı gibi, 2011 yılında meydana gelen Van Depreminde basın organlarına yansıyan yağma vb. olumsuz görüntüleri de engelleyecektir (Sabah, Erciş’te Yağmacılar İş Başında, 2011).

TAMP'ın organizasyonel yapısına ilişkin bir diğer sorun alanı ise, esasen kendi içerisinde iki farklı sorun alanını barındıran hizmet gruplarının kendisinden kaynaklanmaktadır. Şöyle ki TAMP'ın omurgasını oluşturan hizmet gruplarının kendi iç yönetimlerinin ve hizmet gruplarını oluşturan kurumların sürdürülebilirliğinin de tartışılması gerekmektedir.

Bilindiği üzere bütünleşik ve modern afet yönetimi, koordinasyon esasına dayanmaktadır. Bir başka ifadeyle bugünün afet yönetiminde hiyerarşik emir komuta düzeni yerine katılımcılık 
ve birlikte yönetim temel ilke kabul edilmektedir. Nitekim TAMP da planlama prensipleri içerisinde koordinasyon, işbirliği ve dayanışmaya atıfta bulunmaktadır (TAMP, 2013, s.2). Ancak TAMP'ta organize edilen hizmet gruplarının iç düzeni incelendiğinde, özellikle ana çözüm ortağı olarak tanımlanmış kurumlara verilmiş olan görevlerin, koordinasyondan ziyade bilinen klasik yönetim anlayışına dönük olduğu iddia edilebilecektir.

Şöyle ki, TAMP'ın (2013, s.15) “Ana Çözüm Ortaklarının Sorumluluk ve Görevleri” başlıklı kısmında da görülebileceği üzere, bir hizmet grubunun ana çözüm ortağına verilen hizmet grubu organizasyonunu kurmak, hazırlık ve planlama çalışmalarını yönetmek, destek çözüm ortaklarını göreve çağırmak ve afet bölgesindeki çalışma esaslarını belirlemek gibi görevler, TAMP'ın üzerine inşa edildiği prensiplerle çelişir niteliktedir. Nihayetinde Türkiye'deki afet yönetiminin en çok şikayet edilen yönlendiren birisi olan koordinasyon ve katılımcılık esasının bulunmamasına bir çözüm üretmeye çalışan TAMP, hizmet grubu düzeninde yine emir komuta düzenini uygulamaktadır.

Ancak bu noktada, katılımcılık ve koordinasyonla, dikey hiyerarşik yapı üzerinde de durulması gerekecektir. Hizmet grubu iç işleyişinin bu yönden eleştirisi, temel olarak TAMP'ın kendi prensipleriyle çelişir olması üzerinedir. Fakat aynı zamanda TAMP, idari olarak dikey hiyerarşik bir düzenle de organize edilmiş olduğundan, amir veya yönetici konumunda bulunanların klasik yönetim anlayışı içerisinde hareket etmeleri beklenmelidir. Nitekim, çok sayıda kamu kurumunun ulusal düzeyde $A F A D$, yerel düzeydeyse Vali başkanlığında bir araya geldiği bir düzenin doğal yapısı, hiyerarşik olmayı da beraberinde getirmektedir.

Fakat bu gereklilikle, hizmet grubu düzeninin bir araya getirilmesi de, ayrı ve yeni bir çelişkiyi ortaya çıkarmaktadır. Bilindiği üzere olay komuta sistemi, farklı grup ve birimlerin bir arada çalışmalarını esas almaktadır (Kadıoğlu, 2011, s.117). Bu bakımdan hizmet grubu düzeninin olay komuta sistemi içerisindeki yeri de, bu esas doğrultusunda oluşturulmuştur. Bir başka ifadeyle hizmet grubu, bir arada çalışacağı düşünülen kurumların yerleştirildiği, hizmet esaslı bir grubu işaret etmektedir. Bu bakımdan, özellikle Türkiye gibi, kurumsal aidiyetin ve bürokratik prensiplerin hakim olduğu kamu kurumlarının bir hizmet etrafında bir araya getirilmesinin ve içlerinden bir tanesinin yönetici olarak tanımlanmasının, ilgili hizmetin sürdürülebilmesi açısından engel teşkil edebileceği, değerlendirilmelidir.

TAMP'ın organizasyonel düzenine ilişkin bir diğer önemli sorun alanı da, hizmet gruplarını oluşturan kurumların sürdürülebilirliği olacaktır. Sonuç olarak hizmet grupları üzerinden işletilmek istenen TAMP'ta hizmet gruplarına verilmiş bulunan görevler, kamu kurumları tarafından yerine getirilecektir. Ancak TAMP metni içerisinde, görev verilen kurumların, afet sırasındaki çalışabilirliklerine veya iş sürekliliklerine yer verilmediği görülmektedir. Her ne kadar Afet ve Acil Durum Müdahale Hizmetleri Yönetmeliğinin "Acil Durum Planı" başlıklı 10. Maddesinde, "Kamu kurum ve kuruluşları ile özel kuruluşlara ait bina ve tesisler için acil durum planları (...) İşyerlerinde Acil Durumlar Hakkında Yönetmelik hükümleri çerçevesinde hazırlanır" hükmü bulunsa da atıf yapılan yönetmelik, iş sürekliliğinin sağlanması yerine, 6331 sayılı İş Sağlığı ve Güvenliği Kanunu kapsamındaki işyerlerinde meydana gelebilecek acil durumlarda yapılacak müdahale ile sınırlıdır (İşyerlerinde Acil Durumlar Hakkında Yönetmelik, md.1). Ayrıca ilgili yönetmeliğin yasal dayanağı olan 6331 sayılı İş sağlığı ve Güvenliği Kanununa göre de afet ve acil durum birimlerinin müdahale faaliyetleri, kanun kapsamı dışında bırakılmıştır (md. 2/2/b).

$\mathrm{Bu}$ nedenle, olası bir afet durumunda, özellikle yerel düzeyde afete müdahale etmekle görevli kurumların ve bu kurumların personelinin de afetzede konumunda olabileceği düşünüldüğünde, TAMP'ta tanımlı görevlerin yerine getirilmesinin büyük oranda aksayabileceği, dikkate alınmalıdır. 
TAMP'ın organizasyon yapısı içerisinde, hizmet gruplarına verilen yetki ve sorumluluklardan kaynaklanan bazı sorun alanları da bulunmaktadır. Şöyle ki, normal koşullar altında, yürütülen hizmetin bütünlüğü içerisinde gerçekleştirilmesi gereken bazı alt eylemlerin, farklı hizmet gruplarının görevi olarak tanımlanmasının, operasyonel verimliliği düşüreceği iddia edilebilecektir.

Örneğin, Nakliye Hizmet Grubuna verilen "görevli personelin konuşlanma alanı ile operasyon alanı arasındaki naklini sağlamak" görevi, herhangi bir işin yürütülebilmesi amacıyla, işi yapacak kişi veya kurumun işin gerçekleştirileceği yere gitmesi doğal sürecini kesintiye uğratacak niteliktedir. Hele ki, söz konusu faaliyetlerin bir afet sonrasında yürütülen çalışmalar olduğu düşünüldüğünde, bu çalışmalarda görev alacak tüm kurum ve kuruluşların, özellikle yurt içinde, işin gereğini yerine getirebilecek ulaşım altyapısına sahip olması, yapılacak işin tabiatı gereğidir ${ }^{11}$.

Türkiye'de TAMP ekseninde analiz edilen afet müdahale çalışmalarına ilişkin ifade edilebilecek bir diğer sorun alanıysa, AFAD'ın gerek Türk afet yönetimi sisteminde gerekse müdahale süreçleri içerisinde kendisini konumlandırdığı yer olarak karşımıza çıkmaktadır. Şöyle ki AFAD, resmi internet sitesinde kendisini "Afet ve Acil Durum Yönetimi Başkanlığı, afetlerin önlenmesi ve zararlarının azaltılması, afetlere müdahale edilmesi ve afet sonrasındaki iyileştirme çalışmalarının süratle tamamlanması amacıyla gereken faaliyetlerin planlanması, yönlendirilmesi, desteklenmesi, koordine edilmesi ve etkin uygulanması için ülkenin tüm kurum ve kuruluşları arasında işbirliğini sağlayan, çok yönlü, çok aktörlü, bu alanda kaynakların rasyonel kullanılmasını gözeten, faaliyetlerinde disiplinler arası çalışmayı esas alan iş odaklı, esnek ve dinamik yapıda teşkil edilmiş bir kurumdur" (AFAD, 2019c) şeklinde tanıtmaktadır.

Tanıtım metni içerisinde kullanılan ifadeler incelendiğinde, çalışmanın ilgili bölümlerinde de yer verilen modern ve bütünleşik afet yönetiminin gereklerinin ve işleyişinin vurgulandığı görülmekle birlikte AFAD'ın, Türk afet yönetiminin çatı ve koordinatör kurumu olduğu da anlaşılabilmektedir. Nitekim, özellikle 1999 yılında meydana gelen depremlerden sonra "uyanış dönemi"ne giren ve köklü bir değişim geçiren Türk afet yönetiminin de, kaynakların etkin ve verimli bir şekilde kullanılmasını sağlayacak bir üst koordinatör kuruma olan ihtiyacı, ortak görüş olmuştur.

Ancak, TABLO 2'de gösterilen hizmet grupları ve ana çözüm ortakları eşleşmesinde, AFAD'ın hem ulusal hem de yerel seviyede on adet hizmet grubunun ana çözüm ortağı olduğu görülebilmektedir. TAMP'ın taktik seviye bir müdahale planı olduğu değerlendirildiğinde bu durumun, AFAD'ın koordinatör üst kuruluş rolü yerine operasyonel rolüyle de sistemin içerisinde yer alması gerekliliğini ortaya çıkarmaktadır. Taktik seviyedeki müdahale süreçlerine yoğunlaşan AFAD'ın, afet yönetiminin tüm evrelerinde ihtiyaç duyulan koordinatör ve yönlendirici rolünü olumsuz etkileyebileceği değerlendirilebilecektir.

\section{SONUÇ VE ÖNERILER}

Türkiye Afet Müdahale Planının yönetim bilimi ve afet yönetimi açısından analizini yaparak, tespit edilen sorun alanlarına ilişkin çözüm önerileri sunmak iddiasında olan bu çalışma içerisinde, Türkiye Afet Müdahale Planının gerek yasal altyapısı gerekse planlama ve organizasyon süreçleri anlamında birçok sorun alanının bulunduğu tespit edilmiştir. Bütün Türkiye'nin afet müdahale süreçleri için yol gösterici bir doküman olma iddiasında olan

\footnotetext{
${ }^{11}$ Uluslararası operasyonlardaki intikal süreçleri ve INSARAG kuralları, yurt içi yerel müdahale çalışmaları değerlendirilerek inmal edilmiştir (Y.N.).
} 
TAMP için, şüphesiz ki tespit edilen bu sorun alanlarının da çözüme kavuşturulması gerekecektir.

İlgili sorun alanlarına ilişkin tartışma ve değerlendirmelerin yer aldığı önceki bölümden de anlaşılabileceği üzere Türkiye'nin, öncelikle afet yönetimine ilişkin uzun dönemli bir ulusal stratejiye ve bu stratejiyi destekleyecek, Anayasa'da yer alan olağanüstü yönetim usulleriyle çelişmeyen yeni ve tek bir yasal altyapıya intiyacı olduğu ortaya çıkmaktadır. Bu bakımdan öncelikle bu iki sorunun çözüme kavuşturulmasıyla, uygulamaya yönelik sorunların çözümüne ilişkin de önemli bir adım atılmış olacaktır.

Tespit edilen diğer sorun alanları için de;

i. Afet yönetimindeki planlama süreçlerini deprem odaklı olmaktan çıkararak, çağın ve modern afet yönetiminin intiyaç ve prensipleri doğrultusunda süreçlerin, Türkiye'nin afetselliği dikkate alınarak tüm tehditler yaklaşımıyla yeniden tanımlanması;

ii. Özellikle ulusal seviyede, saha yönetiminin ihtiyaç ve özelliklerine göre kurgulanmış olay komuta sistemi yerine çoklu kurum koordinasyon sistemlerinin geliştirilerek kullanılması;

iii. TAMP'ın operasyon, planlama, lojistik ve finans servislerinin yönetimi ve bağlı hizmet gruplarının koordinasyonu için dört ayrı servis planının tanımlanması;

iv. TAMP içerisinde tespit edilen bazı görev çakışmalarının netleştirilmesi ve asıl işin yerine getirilmesi süreçlerini bölmeyecek şekilde görev ve sorumlulukların yeniden dağıtılması;

v. Özellikle yerel düzey dikkate alındığında operasyonel ekipler ve lojistik ekipler olarak organize edilmiş olan hizmet gruplarının bu organizasyon düzeninin revize edilerek hizmet gruplarının ve hizmet gruplarını oluşturan kurumların da operasyonel seviyede olay komuta sistemini kullanmasının sağlanması;

vi. TAMP'ta görevli tüm kurumların hem ulusal hem de yerel seviyede iş sürekliliği süreçlerinin tamamlanması ve iş sürekliliği uygulamasının ulusal ve yerel planlarla entegre bir biçimde hızı bir şekilde hayata geçirilmesi ve yasal altyapıya kavuşturulması;

önerilmektedir.

Sonuç olarak hem AFAD hem de TAMP, Türkiye'nin afetselliğinin ve içerisinde bulunduğumuz yüzyılın afet yönetimi açısından gerekliliklerinin birer ürünü olarak ortaya çıkmıştır. Her ne kadar TAMP'ın buraya kadar aktarılan bir çok sorun alanı bulunsa da, Türkiye gibi hem doğal hem de insan kaynaklı afetlere maruz bir ülkenin ulusal ölçekte müdahale stratejisini tanımlayan bir plana olan intiyacı ortadadır. Bu nedenle, tespit edilen sorun alanlarının çözüme kavuşturulmasıyla TAMP'ın hem ulusal hem de yerel seviyede daha uygulanabilir bir plan haline getirilmesi Türkiye açısından önem arz etmektedir.

Ayrıca, TAMP'ın hazırlayıcısı ve uygulayıcısı olarak AFAD'ın da, sorun alanları içerisinde de değinilen "rolünün" netleştirilmesi, Türkiye'nin afet yönetimi stratejilerinin yararına olacaktır. $\mathrm{Bu}$ noktada, şüphesiz ki bazı özel intiyaçlar ortaya çıktığında bünyesindeki kaynakları kullanacak olmakla birlikte AFAD'ın, esasen Türk afet yönetiminin üst kuruluşu rolünü benimseyerek stratejik planlama ve koordinasyon süreçlerinde ağırlıklı olarak yer alması gerekliliği değerlendirilmelidir. 


\section{KAYNAKLAR}

Afet İşleri Genel Müdürlüğü. (2000). 17 Ağustos 1999 İzmit Körfez Depremi Raporu. Ankara. Afet ve Acil Durum Müdahale Hizmetleri Yönetmeliği. (2013, Aralık 18). Haziran 01, 2019 tarihinde T.C. Resmi Gazete 28855: http://www.resmigazete.gov.tr/eskiler/2013/12/20131218-13.htm adresinden alındı

Afet ve Acil Durum Yönetimi Başkanlığı (AFAD). (2014). Müdahale, lyileştirme ve Sosyoekonomik Açıdan 2011 Van Depremi. Haziran 15, 2019 tarihinde https://www.afad.gov.tr/upload/Node/17944/xfiles/mudahale_-iyilestirme-ve-sosyoekonomikacidan-2011-van-depremi-raporu_2_.pdf adresinden alındı

Afet ve Acil Durum Yönetimi Başkanlığı (AFAD). (2018). Türkiye'de Afet Yönetimi ve Doğa Kaynaklı Afet Istatistikleri. Ankara: Afet ve Acil Durum Yönetimi Başkanlığı. Haziran 01, 2019 tarihinde adresinden alındı

Afet ve Acil Durum Yönetimi Başkanlığı (AFAD). (2019a, Mayıs 21). BM Afet Risklerinin Azaltılması Küresel Platformu'nda Türkiye Üst Düzeyde Temsil Edildi. Haziran 05, 2019 tarihinde https://www.afad.gov.tr/tr/38193/BM-Afet-Risklerinin-Azaltilmasi-Kuresel-Platformunda-Turkiye-Ust-Duzeyde-Temsil-Edildi adresinden alındı

Afet ve Acil Durum Yönetimi Başkanlığı (AFAD). (2019b). Van Depremi Hakkında. Haziran 16, 2019 tarihinde https://www.afad.gov.tr/tr/2385/Van-Depremi-Hakkinda adresinden alındı

Afet ve Acil Durum Yönetimi Başkanlığı (AFAD). (2019c). AFAD Hakkında. Haziran 17, 2019 tarihinde https://www.afad.gov.tr/tr/2211/AFAD-Hakkinda adresinden alındı.

Afet ve Acil Durum Yönetimi Başkanlığı (AFAD). (2020). Açıklamalı Afet Yönetimi Terimleri Sözlügü. Mart 01, 2020 tarihinde https://www.afad.gov.tr/aciklamali-afet-yonetimi-terimlerisozlugu adresinden alındı

Afetlere İlişkin Acil Yardım Teşkilatı ve Planlama Esaslarına Dair Yönetmelik. (1988, Mayıs 08). Haziran 02, 2019 tarihinde T.C. Resmi Gazete, 19808: http://www.resmigazete.gov.tr/arsiv/19808.pdf adresinden alındı

Aktan, C. C. (2003). Değişim Çağında Yönetim. İstanbul: Sistem Yayınları.

Bates, F., \& Peacock, W. (1993). Living Conditions, Disasters and Development. Athens: University of Georgia Press.

Belediye Kanunu. (2005, Temmuz 13). Mayıs 29, 2019 tarihinde T.C. Resmi Gazete, 25874: http://www.resmigazete.gov.tr/eskiler/2005/07/20050713-6.htm adresinden alındı

Bolin, R. (1989). Natural Disasters. R. Gist, \& B. Lubin içinde, Psychosocial Aspects of Disaster (s. 61-85). New York: John Wiley and Sons.

Büyükşehir Belediyesi Kanunu. (2004, Temmuz 23). Mayıs 29, 2019 tarihinde T.C. Resmi Gazete, 25531: http://www.resmigazete.gov.tr/eskiler/2004/07/20040723.htm\#1 adresinden alındı

Canton, L. G. (2007). Emergency Management Concept and Strategies for Effective Programs. New Jersey: John Wiley and Sons.

Çevik, H. H. (2001). Organizasyonlarda Stratejik Yönetim. S. Güney içinde, Yönetim ve Organizasyon (s. 309-321). Ankara: Nobel Yayınları.

Daft, R. L. (2009). Management (9. b.). USA: South Western Cengage Learning.

Drabek, T. E. (2007). Sociology, Disasters and Emergency Management: History, Contributions, and Future Agenda. D. A. McEntire içinde, Disciplines, Disasters and 
Emergency Management: The Convergence and Divergence of Concepts, Issues and Trends in The Research Literature (s. 61-74). Illinois: Charles C Thomas Publisher Ltd.

Dynes, R. (1998). Coming to Terms With Community Disaster. E. L. Quarantelli içinde, What Is A Disaster? Perspectives on The Question (s. 109-126). London: Routledge Publications.

Gilbert, C. (1998). Studying Disaster: Changes in The Main Conceptual Tool. E. L. Quarantelli içinde, What Is A Disaster? Perspectives on The Question (s. 11-18). London: Routledge Publications.

Gözler, K. (2011). Türk Anayasa Hukuku Dersleri (12. b.). Bursa: Ekin Basım Yayım Dağıtım. Hancılar, U., Şeşetyan, K., \& Çaktı, E. (2017). İstanbul'daki 2000 Yılı Sonrası Binalar İçin Tasarım Depremi Altında Yapısal Hasar ve Mali Kayıp Tahminleri. 4. Uluslararası Deprem Mühendisliği ve Sismoloji Konferansı, 11-13 Ekim 2017. Eskişehir: Anadolu Üniversitesi.

II Özel Idaresi Kanunu. (2005, Mart 04). Mayıs 30, 2019 tarihinde T.C. Resmi Gazete, 25745: www.resmigazete.gov.tr/eskiler/2005/03/20050304-1.htm adresinden alındı

İstanbul Büyükşehir Belediyesi. (2009a). İstanbul Olası Deprem Kayıp Tahminleri. Haziran 15, 2019 tarihinde http://www.ibb.gov.tr/trTR/SubSites/DepremSite/Documents/C_\%C4\%B0STANBUL\%E2\%80\%99UN\%20OLASI\%2 ODEPREM\%20KAYIPLARI\%20TAHM\%C4\%B0NLER\%C4\%B0-rapor.pdf adresinden alındı

İstanbul Büyükşehir Belediyesi. (2009b). İstanbul'un Olası Deprem Kayıpları Tahminlerinin Güncellenmesi İşi (İstanbul Deprem Senaryosu) Yönetici Özeti. Haziran 15, 2019 tarihinde http://www.ibb.gov.tr/tr-

TR/SubSites/DepremSite/Documents/\%C4\%B0stanbul\%20Deprem\%20HT\%C3\%87_N\%C4 \%BOSAN\%202012.pdf adresinden alındı

Iş Sağlığı ve Güvenliği Kanunu. (2012, Haziran 30). Haziran 01, 2019 tarihinde T.C. Resmi Gazete, 28339: http://www.resmigazete.gov.tr/eskiler/2012/06/20120630-1.htm adresinden alındı

İşyerlerinde Acil Durumlar Hakkında Yönetmelik. (2013, Haziran 18). Haziran 01, 2019 tarihinde T.C. Resmi Gazete, 28681: http://www.resmigazete.gov.tr/eskiler/2013/06/20130618-8.htm adresinden alındı

Kadıoğlu, M. (2011). Afet Yönetimi Beklenilmeyeni Beklemek En Kötüsünü Yönetmek. İstanbul: T.C. Marmara Belediyeler Birliği Yayınları Yayın No:65.

Kalkınma Bakanlığı. (2013). Onuncu Kalkınma Planı 2014-2018. Ankara.

Kapani, M. (1981). Kamu Hürriyetleri (6. b.). Ankara: Ankara Üniversitesi Hukuk Fakültesi Yayınları Yayın No:453.

Karancı, N. (2005). Afetzede Psikolojisi ve Hazırıklı Olma / Zarar Azaltma Davranışları. M. Kadıoğlu, \& E. Özdamar içinde, Afet Yönetiminin Temel İlkeleri (s. 93-99). Ankara: JICA Türkiye Ofisi Yayın No:1.

Kuzu, B. (1993). Olağanüstü Hal Kavramı ve Türk Anayasa Hukukunda Olağanüstü Hal Rejimi. İstanbul: Kazancı Yayınları.

Olağanüstü Hal Kanunu. (1983, Ekim 27). Mayıs 20, 2019 tarihinde T.C. Resmi Gazete, 18204: http://www.resmigazete.gov.tr/arsiv/18204.pdf adresinden alındı

Parlak, B. (2013). Yönetim Bilimi ve Çağdaş Yönetim Teknikleri (2. b.). İstanbul: Beta Basım Yayım Dağıtım.

Pelling, M. (2003). The Vulnerability of Cities Natural Disasters and Social Resilience. London: Earthscan Publications. 
Perry, R. W. (2007). What Is A Disaster? H. Rodriguez, E. Quarantelli, \& R. Dynes içinde, Handbook of Disaster Research (s. 1-15). New York: Springer Publications.

Quarantelli, E. L. (2000). Disaster Research. E. Borgatta, \& R. Montgomery içinde, Encyclopedia of Sociology (2 b., Cilt 1, s. 682-688). New York: Macmillian Reference.

Quarantelli, E. L. (2003). Urban Vulnerability to Disasters in Developing Countries: Managing Risks. A. Kreimer, M. Arnold, \& A. Carlin içinde, Building Safer Cities: The Future of Disaster Risk (s. 211-231). Washington D.C.: The World Bank Disaster Management Facility.

Quarantelli, E. L. (2005). A Social Science Research Agenda for The Disasters of The 21st Century. R. Perry, \& E. Quarantelli içinde, What Is A Disaster? New Answers to Old Questions (s. 325-396). USA: Xlibris Corporation.

Sabah. (2011, Ekim 26). Erciş'te Yağmacılar İş Başında. Haziran 16, 2019 tarihinde https://www.sabah.com.tr/gundem/2011/10/26/erciste-yagmacilar-is-basinda-541905503408 adresinden alındı

Sivil Savunma Kanunu. (1958, Haziran 13). Mayıs 21, 2019 tarihinde T.C. Resmi Gazete, 9931: http://www.resmigazete.gov.tr/arsiv/9931.pdf adresinden alındı

Şahin, A. U. (2014). Afet Yönetimi Faaliyetlerinin Kamu Hizmeti Kavramı Çerçevesinde Değerlendirilmesi. TESAM Akademi, 1(2), 7-30.

TAMP-HATAY. (2019, Mart 11). Hatay II Afet ve Acil Durum Müdürlüğü Türkiye Afet Müdahale Toplantısı Bilgilendirme Sunumu. Hatay Mustafa Kemal Üniversitesi Hatay Sağlık Yüksekokulu.

Tanör, B., \& Yüzbaşığlu, N. (2002). 1982 Anayasasına Göre Türk Anayasa Hukuku (4. b.). İstanbul: Yapı Kredi Yayınları.

Tierney, K. J. (1989). The Social and Community Contexts of Disasters. R. Gist, \& B. Lubin içinde, Psychosocial Aspects of Disaster (s. 11-39). New York: John Wiley and Sons.

Tortop, N., İsbir, E., Aykaç, B., Yayman, H., \& Özer, M. (2010). Yönetim Bilimi (8. b.). Ankara: Nobel Yayın Dağıtım.

Tunçer, P. (2012). Yönetim ve Organizasyon. İstanbul: Beta Yayınları.

TÜİK, Türkiye İstatistik Kurumu. (2019). Adrese Dayalı Nüfus Kayıt Sistemi Yıllara Göre II Nüfusları. Haziran 16, 2019 tarihinde http://www.tuik.gov.tr/PreTablo.do?alt_id=1059 adresinden alındı

Türkiye Afet Müdahale Planı (TAMP). (2013, Aralık). Mayıs 15, 2019 tarihinde Afet ve Acil Durum Yönetimi Başkanlığı: https://www.afad.gov.tr/upload/Node/2419/files/Afet_Mud_PI_ResmiG_20122013.pdf adresinden alındı

Türkiye Cumhuriyeti Anayasası. (1982, Kasım 09). Mayıs 17, 2019 tarihinde T.C. Resmi Gazete, 17863 (Mükerrer): http://www.resmigazete.gov.tr/arsiv/17863_1.pdf adresinden alındı

Twigg, J. (2015). Disaster Risk Reduction. London: Overseas Development Institute.

Ulusal Düzey Hizmet Grubu Plan Şablonu. (2014). Haziran 06, 2019 tarihinde https://www.afad.gov.tr/tr/9215/TAMP-Dokumanlari adresinden alındı

Ulusal Radyasyon Acil Durum Planı (URAP). (2020). Mart 01, 2020 tarihinde Afet ve Acil Durum Yönetimi Başkanlığı (AFAD): https://www.afad.gov.tr/ulusal-radyasyon-acil-durumplani-urap adresinden alındıUmumi Hayata Müessir Afetler Dolayısiyle Alınacak Tedbirlerle Yapılacak Yardımlara Dair Kanun. (1959, Mayıs 25). T.C. Resmi Gazete, 10213: http://www.resmigazete.gov.tr/arsiv/10213.pdf adresinden alınmıştır 
United Nations International Strategy For Disaster Reduction (UNISDR). (2009). Terminology on Disaster Risk Reduction. Geneva: United Nations International Strategy For Disaster Reduction.

USGS, U.S. Geological Survey. (2019a). 23 Ekim Van Depremi Yoğunluk Haritası. Haziran 16 , 2019 tarihinde https://earthquake.usgs.gov/earthquakes/eventpage/usp000j9rr/shakemap/intensity adresinden alındı

USGS, U.S. Geological Survey. (2019b). 17 Ağustos Marmara Depremi Yoğunluk Haritası. Haziran 16 , 2019 tarihinde

https://earthquake.usgs.gov/earthquakes/eventpage/usp0009d4z/shakemap/intensity adresinden alındı 